

\section{Smithsonian Institution}

Sibraries

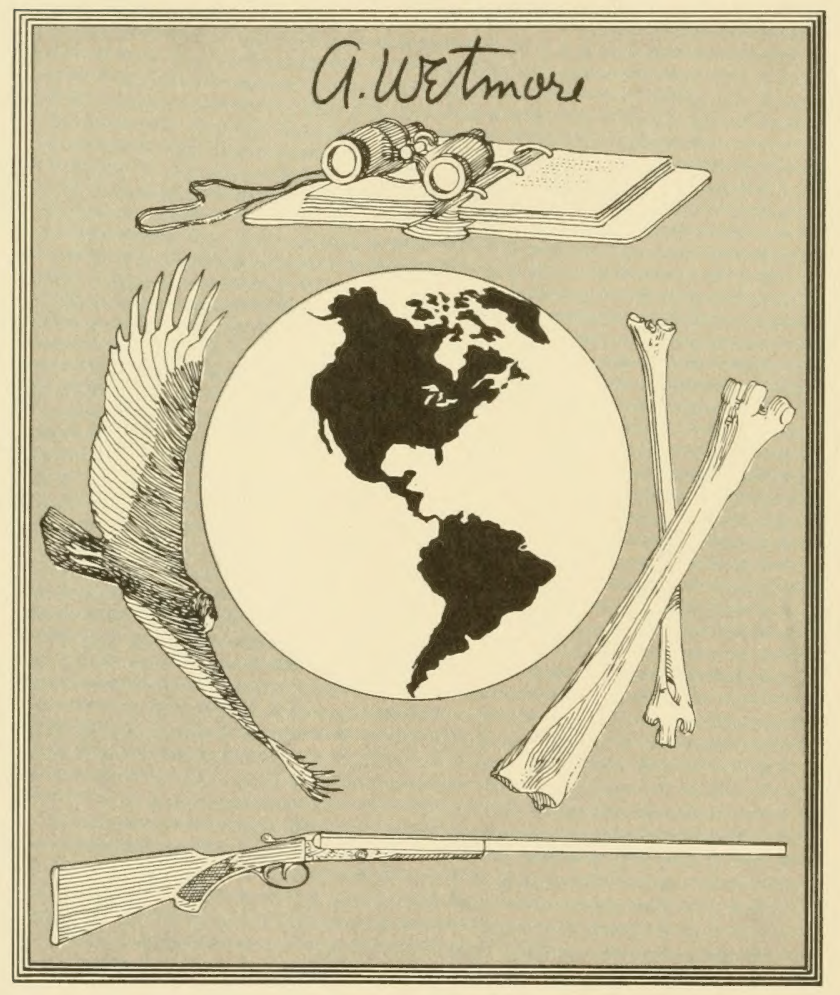

Alexander Wetmore

1946 SixthSecretary 1953

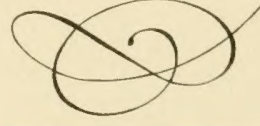


Q. Wrtmore 




\section{CONTRIBUTIONS}

TO THE

\section{ORNITHOLOGY OF SIBERIA.}

BY

HENRY SEEBOHM.

During the last few years considerable efforts have been made, principally by Professor Nordenskiöld of Stockholm and Captain Wiggins of Sunderland, to reopen to European commerce the ancient route to Siberia through the Kara Sea. Last year (1876) Captain Wiggins left Sunderland on the 8th of July in the arctic steam-yacht 'Thames' (about 120 tons), and entered the Kara Sea on the 3rd Aug. He spent some time in surveying the coast, and anchored in the gulf of the Obb on the 7th of Sept. On the 23rd of Sept. he began to ascend the Yen-e-say'*; and on the 17th of October he had succeeded in making about a thousand knots

* In this paper I have endeavoured to spell all the Russian proper names phonetically, showing also the syllable upon which the accent must be laid, a matter of great importance in the Russian language. 
against stream, and laid his vessel up in winter-quarters just within the entrance of the Koo-ray'-i-ka river, on the arctic circle, where she was frozen up the next morning. When the ice on the river had frozen sufficiently hard to make sledging safe, Capt. Wiggins left his ship in charge of the crew, and returned to England by the overland route.

I did not meet Capt. Wiggins until the 24th of February; but finding that he was intending to return to his ship almost immediately, I came to the conclusion that an opportunity of visiting the Yen-e-say' in company with a gentleman who knew the way so well might never occur again, and I hastily made up my mind to return with the captain to his ship, and take my chance of coming home in her by the Kara Sea. I am much indebted to Count Schouvaloff for kindly providing me, almost at a moment's notice, with letters of introduction, which proved of the greatest service to me.

We left London on the evening of the 1st of March, and, after spending a few days in St. Petersburg, reached Nishni Novgorod on the morning of the 10th, a distance of about 2400 English miles. At Nishni we bought a sledge, and travelled over the snow 3240 English miles, employing for this purpose about a thousand horses, sixteen dogs, and forty reindeer. We left Nishni on the evening of the 10th of March, and travelled day and night in a generally easterly direction, stopping a couple of days at Tyn-maiu', and a day at Omsk, and reached Kras-no-yarsk' on the morning of the 2nd of April, soon after crossing the meridian of Calcutta. We rested a day in Kras-no-yarsk', and sledged thence nearly due north, spending four days in Yen-e-saisk' and three days in Toor-o-kansk', and reached the 'Thames' on the Kooray'-i-ka in the afternoon of the 23rd of April.

For the first few days we found sledge-travelling somewhat irksome; but we soon got into the full swing of it. After having sledged a thousand miles or so, we began to feel that the process might go on for weeks or months, or even years, without serious results. I soon began to enjoy it. My sledge-fever entirely left me; and I used to find a pleasant lullaby in the never ceasing music of the "wrangling and the 
jangling of the bells." However rough the road was, I enjoyed a good night's rest; and if an unusually heavy "lee lurch," or "weather roll," jolted me against my companion, we only muttered that there was "a heavy sea on," and dozed off again. Snow, wind, rain, sunshine, day, night, hills, valleys, plains, rivers, good roads, bad roads, it was all the same; on we went, and nothing stopped us. The scenery through which we passed was very various. The first thousand miles was hilly and well wooded. One might imagine one was sledging through an endless Sherwood Forest, with a hundred miles of the Peak of Derbyshire placed in the middle to represent the Urals. The ground was covered with from two to three feet of snow. Sometimes we seemed to be sledging down a "broad drive," sometimes crossing a peak, and occasionally passing through a village. The forests were principally spruce-fir, with a little larch and Scotch fir, and plenty of birches. Sometimes we sledged for miles through avenues of pines. The Ural range is a succession of hills, which it took us some time to get through; but the loftiest peak can scarcely be dignified with the name of mountain. Between Tyu-main' and Tomsk we had nearly a thousand miles of a totally different class of scenery. The steppes of South-western Siberia might be compared to Salisbury plains. As far as the eye could reach, nothing was visible but snow, sky, and telegraph-lines. Now and then we came upon a few stunted birches; and every fifteen or twenty miles we passed through a village. About a hundred miles before reaching Tomsk we again found ourselves amongst hills and forests, which continued until the road permanently established itself down the broad river.

The Yen-e-say' is said to be the third largest river in the world. In Yen-e-saisk' the inhabitants claim that the waters of their river have flowed at least two thousand miles (through Lake By-kal') to their town. In Yen-e-saisk' the river must be more than a mile wide. From Yen-e-saisk' to the Koo-

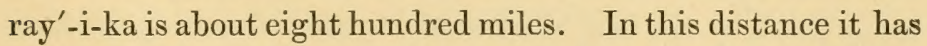
gradually increased to a little more than three miles wide. From the Koo-ray'-i-ka to the limit of forest-growth, where 
the delta may be said to begin, is generally reckoned at another eight hundred miles, for which distance the river will average at least four miles in width. To this we must add a couple of hundred miles of delta, and another couple of hundred miles of lagoon, each of which will average twenty miles in width, if not more.

When we reached the ship we found the crew well and hearty. They had been amply provided with lime-juice and dried vegetables; and no symptoms of scurvy presented themselves. On the other hand, we afterwards learned that the crew of a Russian schooner, which had wintered four degrees further north without having been supplied with these wellknown preventives, had suffered so severely from scurvy that only the mate survived the winter.

Our winter-quarters were very picturesque. The 'Thames' was moored close to the north shore of the Koo-ray'-i-ka, at the entrance of a little gully, into which it was the captain's intention to take his ship as soon as the water rose high enough to admit of his doing so, and where he hoped to wait in safety the passing away of the ice. On one side of the ship was the steep bank of the river, about a hundred feet in height, and covered with snow, except here and there, where it was too perpendicular for the snow to lie. On the top of the bank was the house of a Russian peasant and merchant, with stores and farm-buildings adjacent, and a bath-house, occupied by an old man who earned a living by making casks. One of the rooms in this house was occupied by the crew of the 'Thames ;' and after they had returned to the ship I and my servant took possession and made it our headquarters for bird-skinning \&c. As we stood at the door of this house, on the brow of the hill, we looked down onto the "crow's-nest" of the 'Thames.' To the left the Kooray'-i-ka, a mile wide, stretched away some four or five miles, until a sudden bend concealed it from view; whilst to the right the eye wandered across the snow-fields of the Yene-say', and by the help of a binocular the little village of Kooray'-i-ka might be discerned about four miles off, on the opposite bank of the great river. The land was undulating 
rather than hilly, and everywhere covered with forest, the trees reaching frequently two, and in some rare instances three, feet in diameter. The depth of the suow varied from four to six feet; and travelling without snow-shoes, except on the hard-trodden roads, was of course utterly impossible. I generally marle two rounds a day through the forest, and soon exhausted the ornithology of the district. During the first week I succeeded in identifying twelve species of birds. For the next four weeks I only increased my list by a weekly average of three species. June is the month in which nearly all migratory birds arrive in the arctic circle. In the three wceks between the 29th of May and the 18th of June I added sixty-five birds to my list, and afterwards only occasionally picked up a new bird which had escaped my notice.

We experienced great variety of weather on our journey out. In St. Petersburg we alternated between a slight thaw and a gentle frost. In Moscow and Nishni the snow was melting rapidly. On the Volga we had occasionally to sledge through a foot of water and half-melted snow. Over the Ural hills we had bright sunshine and hard frost. Across the steppes the weather was mild, but there was no absolute thaw, and we had now and then slight snow-storms. After leavingTomsk the weather became decidedly milder; and when we reached Kras-no-yarsk' we found a warm south-wester blowing, the streets running with water, and everybody travelling on wheels. Our journey northwards was a complete race with the south wind. 'The red hills of Kras-no-yarsk' were already bare of snow; the south-wester continued blowing as warm as ever; sledge-travelling had, for the time being become impossible, and we were obliged to organize a caravan. For two stages we travelled in a tyel-ay'-ga, with one tar-an-tass' for our baggage, and a second for the empty sledge. For the next two stages the road was covered with snow, though it was somewhat soft; but we dismissed a couple of our equipages, travelling ourselves in the sledge, and retaining only one tar-an-tass' for the baggage. For the rest of the journey to Yen-e-saisk' we had brilliant sunshine and hard roads. The south wind, however, overtook us before we left 


\section{Mr. H. Seebohm on the Ornithology of Siberia.}

that town, and for some days we had very sloppy travelling; but we pressed on day and night until we reached the entrance to the Kah' -min Pass, the most dangerous part of the journey, where the river flows through a comparatively narrow defile, between high walls of limestone rocks, with such velocity that in the middle of the stream open water remains all the winter. We reached the station before this pass in the evening, in a drenching rain, the first shower we had experienced, and were told that it was impossible to proceed until a frost should set in. When we rose in the morning we were both surprised and delighted to find the thermometer at or near zero; and the remainder of our journcy was accomplished without a thaw. When we arrived at the ship, we found that it was still winter, and were told that there had not been a sign of rain since last autumn. April went by and May came in, but still there was no sign of summer, except the arrival of some of the earliest migratory birds. We generally had a cloudless sky; and the sun was often burning hot. Here and there, on some steep bank exposed to the south, a slight impression was made upon the snow; but not a drop of water survived the night frosts. On the 9 th, 10th, and 11 th of May we had rain for the first time, and the prospects of summer looked a little more hopeful. The rest of May, however, was more dreary and wintry than ever, alternations of hard frosts and driving snow-storms; but the river was slowly rising, and outside the thick centre ice was a strip of thin newly frozen ice. There was, however, little or no change in the appearance of the snow. Up to the end of May the forces of winter had gallantly withstood the fiercest attacks of the sun, and remained masters of the field. On the lst of June the sun, baffled at all points, entered into an alliance with the south wind, and a combined attack was made upon the winter forces. The battle raged for fourteen days, the battle of the Yen-e-say', the great erent of the year in this cold country, and certainly the most stupendous display of the powers of nature that it has ever been my lot to witness. On the morning of the 1st of Jume the pressure underneath the ice caused a large field, about a mile long and a third of 
a mile wide, opposite the lower angle of junction of the Kooray'-i-ka and the Yen-e-say', to break away. About half the mass found a passage down the strip of newly formed thin ice, leaving open water behind it. The other half rushed headlong onto the steep banks of the river. The result of the collision was a little range of mountains, fifty or sixty feet high, and picturesque in the extreme. Huge blocks of ice, six feet thick and twenty feet long, in many places, were standing perpendicular, whilst others were crushed up into fragments like broken glass; and in many other places the ice was piled up in layers one over the other. The real ice on the river did not appear to have been more than two and a half feet thick, clear as glass, and blue as an Italian sky. Upon the top of this was about four feet of white ice. This was as hard as a rock, and had, no doubt, been caused by the flooding of the snow when the waters of the river had risen, and its subsequent freezing. Upon the top of the white ice was about eighteen inches of clean snow, which had evidently never been flooded. When we turned into our berths in the evening the captain thought it most prudent to institute an anchor-match. We had scarcely been asleep an hour before the watch called us up with the intelligence that the river was rising rapidly, and that the ice was beginning to crack. We immediately dressed and went on deck. We saw at once that the Yen-e-say' was rising so rapidly that it was begining to flow up its tributaries. A strong current was setting up the Koo-ray'-i-ka, and small floes were detaching themselves from the main body of the ice and were running up the open water. By-and-by the whole body of the Kooray'-i-ka ice broke up and began to move up stream. Some of the floes struck the ship some very ugly blows on the stern, doing considerable damage to the rudder; but open water was beyond, and we were soon out of the press of ice, with, we hoped, no irretrievable injury. All this time we had been getting steam up as fast as possible, to be ready for any emergency. It was hopeless to attempt to enter the creek opposite which we were moored, and which was now only just beginning to fill with water; but on the other side 
of the rirer, across only a mile of open water, was a haven of perfect safety. But, alas! when the ice had passed us, before we could get up sufficient steam, the river suddenly fell three feet, and left us aground by the stern, and immovable as a rock. Nor was it possible, with a current running up the river at the rate of four knots an hour, to swing the ship rourd so as to secure the rudder against any further attacks of the ice. Half a mile ahead of us, as we looked lown the river, was the edge of the Yen-e-say' ice. The river was rising again; but before the stern was afloat we discovered, to our dismay, that another large ficld of ice had broken up; and the Koo-ray'-i-ka was soon full of ice again. In the course of the night the whole of the ice on the Yen-e-say', as far as we could see, broke up with a tremendous crash, and a dense mass of ice-floes, pack-ice, and icebergs backed up the Koo-ray'-i-ka, and with irresistible force drove the Koo-ray'-i-ka ice before it. When it reached the ship, we had but one alternative, to slip the anchor and let her drive with the ice. For about a mile we had an exciting ride, pitching and rolling as the floes of ice squeezed the ship, and tried to lift her bodily out of the water, or crawl up her sides like a snake. The rudder was soon broken to pieces, and finally carricd aray. Some of the sailors jumped onto the ice and scrambled ashore, whilst others began to throw overboard their goods and chattels. Away we went up the Kooray'-i-ka, the ice rolling and tumbling and squeezing alongside, huge lumps climbing one on the top of another, until we were finally jammed in a slight bay, along with a lot of pack-ice. Early in the morning the stream slackened, the river fell some five or six feet, and the ice stood still. The ship went through the terrible ordeal bravely. She made no water, and there was no evidence of injury beyond the loss of the rudder. In the evening the ship was lying amidst huge hummocks of ice, almost high and dry. The Koo-ray'i-ka, and right across the Yen-e-say', and southward as far as the eye could reach was one immense field of pack-ice, white, black, brown, blue, and green, piled in wild confusion as close as it could be jammed. Northwards the Yen-e-say' 
was not yet broken up. All this time the weather was warm and foggy, with very little wind, and occasional slight rain. There was a perfect Babel of birds as an accompaniment to the crashing of the ice. Gulls, Geese, and Swans were flying about in all directions; and their wild cries vied with the still wilder screams of the Divers. Flocks of Redpoles and Shore-Larks, and Bramblings and Wagtails in pairs, arrived, and added to the interest of the scene. On the 2nd of June there was little or no movement in the ice until midnight, when an enormous pressure from above came on somewhat suddenly, and broke up the great field of ice to the north of the Koo-ray'$\mathrm{i}-\mathrm{ka}$, but not to a sufficient extent to relieve the whole of the pressure. The water in the Koo-ray'-i-ka rose rapidly. The immense field of pack-ice began to move up stream at the rate of five or six knots an hour. The poor ship was knocked and bumped along the rocky shore, and a stream of water began to flow into the hold. At 9 o'clock all hands left her, and stood upon the snow on the bank, expecting her instant destruction. The stream rose and fell during the day; but the leak, which was apparently caused by the twisting of the stern-post, choked up. Late in the evening an opportunity occurred of a few hours' open water, during which steam was got up; and by the help of a couple of ropes ashore, the rudderless ship was steered into the little creek opposite to which she had wintered, and run ashore. Here the leak was afterwards repaired and a new rudder made. We calculated that about fifty thousand acres of ice passed the ship up stream during these two days; and we afterwards learned that most of this ice got away some miles up the Koo-ray'-i-ka, where the banks were low, and was lost in the forest.

The battle of the Yen-e-say' raged for about a fortnight. The sun was generally burning hot in the daytime; but every night there was more or less frost. The ice came down the Yen-e-say' at various speeds. Sometimes we could see gigantic masses of pack-ice, estimated at twenty to thirty feet in height, driven down the river at an incredible pace, not less than twenty miles an hour. In the Koo-ray'-i-ka the scene was constantly changing. The river alternately rose 
and fell. Many square miles of ice were marched up for some hours, and then marched back again. Sometimes the pack-ice and floes were jammed so tight together that it looked as if one might scramble across the river without difficulty. At other times there was a good deal of open water, and the icebergs "calved" as they went along with much commotion and splashing, that could be heard half a mile off. Underlayers of the iceberg ground; and after the velocity of the enormous mass has caused it to pass on, the pieces left behind rise to the surface, like a whale coming up to breathe. Some of these "calves" must come from a considerable depth. They rise up out of the water with a great splash, and rock about for some time before they settle down to their floating-level. At last the final march past of the beaten winter-forces in this great fourteen days' battle took place, and for seven days more the rag, tag, and bob-tail of the great arctic army came straggling down-worn and weather-beaten little icebergs, dirty ice-floes that looked like mud-bauks floating down, and straggling pack-ice in the last stages of consunption. The total rise of the river was upwards of seventy feet.

The moment that the snow disappeared vegetation sprang up as if by magic, and the birds made preparations for breeding. Although I had taken the precaution of providing myself with a ship, the misfortunes of Capt. Wiggins delayed me on the arctic circle for some weeks. As we passed through Yen-esaisk' I bought a schooner of a ship-builder of the name of Boiling, a Heligolander. I christened it the 'Ibis;' and on the 29th of June we left the Koo-ray'-i-ka with this little craft in tow. Our progress down the river, however, was one catalogue of disasters, ending in our leaving the 'Thames' on the 9 th of July a hopeless wreck, lying high and dry on a sand-bank, in lat. $67^{\circ}$. As we sailed northwards in the 'Ibis' the forests became smaller and smaller, and disappeared altogether about lat. $r 0^{\circ}$. The highest point we reached was lat. $71 \frac{1}{2}^{\circ}$, where I sold the 'Ibis' to the captain of a Russian schooner, which had been totally wrecked during the breakup of the ice. The tundras of Northern Siberia are almost exactly like those of North Russia, and equally gay with 
brilliant flowers and ground-fruits of various kinds, swarming with birds, and alive with mosquitoes. During this voyage we had an excellent opportunity of making the acquaintance of many native tribes, the Ost'-yak, the Tun-goosk', the Dol'gahn, the Yu-rak', and the Sam'-o-yade.

On the 23rd of July I left Gol-cheek' $-a$ in the last Russian steamer up the river, and reached Yen-e-saisk' on the 14th of August. After a few days' delay I drove across country to Tomsk, stopping a day or two in Kras-no-yarsk'. In Tomsk I found an excellent iron steamer, in which I sailed down the river Tom into the $\mathrm{Ob}$, down which we steamed to its junction with the Eer'-tish, up which we proceeded until we entered the Tob-ol', and afterwards steamed up the Too'-ra to Tyu-main', a distance by water of 2200 miles. From Tyumain' I drove through Ekatereenburg across the Urals to Perm, where I took my passage on board the 'Sam-o-lot', or selfflyer, down the Kama, and up the Volga, to Nishni-Novgorod. In St. Petersburg I spent a week, and reached London on the 9th of October, bringing with me more than a thousand skins of birds, about five hundred eggs, and a cart-load of native costumes and other ethological curiosities. I everywhere met with the greatest kindness and courtesy, and am very much indebted to friends, too numerous to mention, who assisted me in many ways during my adventurous journey of more than fifteen thousand miles.

The study of zoology is, I am afraid, more and more neglected in Russia ; but there is still some amount of field-work going on. Taczanowski, the Curator of the Museum at Warsaw, still receives from Dr. Dybowsky ornithological collections from Lake Baical. Professor Strebelow, at Krasno-yarsk', is an accomplished entomologist, and would, I am sure, be glad to assist any European collector. Professor Szoffzoff, at Omsk, is an excellent entomologist, and has also a good knowledge of birds. The Kazan collection is in fair order; but few of the birds in the Museum possess localities or dates, and none of the Professors make ornithology a special branch of study. The Eversmann collection has been sold to the Museum at St. Petersburg for an old song. Sabanaeff, 


\section{Mr. H. Secbohm on the Ormithology of Siberia.}

of Moscow, appears to bave deserted ornithology altogether, and to be immersed in literary pursuits. The splendid collection of birds and eggs which he made in the Ural, and presented to the Museum of Moscow, lies neglected and in disorder, packed away indiscriminately in boxes, cupboards, and drawers ; and many of them are without even a sheet of paper to keep out the dust, or to protect them from moths. I tried unsuccessfully to purchase this unique collection, to save it from destruction. In St. Petersburg, Von Schrenk has, for the time being, forsaken ornithology for the more popular charms of ethmography. The ornithological curator at the museum, Russow, is an enthusiastic field-ornithologist, and is rapidly bringing the chaos of birds in that establishment into excellent order, and will doubtless do good work in the future. St. Petersburg has also an excellent amateur ornithologist in Bogdanoff. At Dorpatt, Von Middendorff has retired, both from the University and from ornithology, to his ancestral estates, and is writing learned treatises on the breeding of horses and cattle. Prjevalsky is an excellent collector, but makes no pretensions to a scientific study of ornithology; and Severtzoff', though he has, as we all know, done good work, has followed too closely the steps of the elder Brehm to satisfy the requirements of modern scientific ornithologists, who aim at hitting the happy medium between "lumpers" and "splitters," but are nevertheless ofttimes sorely puzzled to know on which side of an incipient species to draw the line. 


\section{(Plate IX.)}

The following notes on the birds of Siberia are of course extremely fragmentary. It is very seldom that the first expedition to a strange land is successful. The pioneer can do little more than discover the localities where future researches may be successfully made. My great mistake was that I wintered too far north. Had I waited the arrival of migratory birds at Yen-e-saisk', instead of on the Arctic circle, my ornithological bag would lave been increased fourfold in value. My list is almost as remarkahle for what it omits as for what it includes. There is no doubt that the Merlin is common in the valley of the Yen-e-say'; and a little further south, most likely they would have been found chasing the Snow-Buntings. I was probably only just beyond the northern range of the Siberian Jay. On my return journey my time was necessarily very limited, and I was obliged to husband my ammunition. It was also the most unfavourable time of the whole year for making ornithological observations. During the breeding-season many birds forsake the neighbourhood of the villages and the cultivated land, and scatter themselves through the forests; and whilst they are moulting in the autumn, they seem to be fully aware that their powers of flight are limited, and that consequently they are an easy prey to their Raptorial enemies, and therefore they seem afraid to trust themselves on the wing. For the most part they are silent at this season, and skulk amongst the underwood, and it is only by chance that one can obtain a shot at them.

My plans were also considerably disarranged by the two shipwrecks, which did not form a part of my original programme; nevertheless I trust that the observations I was able to make may prove interesting to the student of ornithology.

Haliaetus albicimla (Linn.).

The Sea-Eagle was common on the banks of the Yen-e-say', 
becoming gradually rarer north of the Arctic circle. I had a fine male brought me which had been caught in a fox-trap.

Archibuteo lagopus (Gmel.).

I frequently saw the Rough-legged Buzzard on the wing near our winter-quarters, but failed to secure a specimen.

Milvus migrans (Bodd.).

I did not notice the Black Kite on the Yen-e-say' until we reached lat. $61^{\circ}$ on the return journey. From this point it increased in abundance as we proceeded south and west, until in Tomsk it swarmed to as great an extent as it does in Constantinople. I did not shoot one of these birds.

Falco peregrinus, Tunstall.

The Peregrine Falcon was first seen on the Koo-ray'-i-ka about the middle of May; and on the 25th of that month I secured a fine male. I once saw one of these birds dash into a flock of Snow-Buntings and bear one off in its talons. On the tundra they were breeding on the steep mud-clifis on the banks of the Yen-e-say'. In lat. $69 \frac{1}{2}^{\circ} \mathrm{I}$ spent the night of the 13th-14th July on shore, shooting. I had no sooner landed than a couple of Peregrines showed me their nest by their loud cries. A glance at the cliffs decided the place where the nest ought to be-on the top of a steep mud promontory, which stretched out to a sharp ridge beyond and above the surrounding coast. I climbed up a valley in which the snow was still lying, and walked straight along the ridge to the little hollow where the four red eggs were placed upon a dozen small flakes of down. The eggs were considerably incubated.

Falco tinnunculus, Linn.

I did not observe the Kestrel until I reached Yen-e-saisk' on my return journey, about the middle of August. The banks of the river to the south of the town are very flat; and a wide extent of meadow-land, which had recently been cut for hay, stretches southward for miles. This plain is surrounded by forests and intersected with numerous half-driedup river-beds running parallel to the Yen-e-say'. In this [14] 
locality I found the Kestrel very abundant, and I frequently saw as many as a score on the wing together. It was also very common on the road-side as we drove through Kras-novarsk' to Tomsk, frequently alighting on the telegraph-posts.

Accipiter nisus (Linn.).

The Sparrow-Hawk was one of the numerous enemies which the Snow-Buntings had to guard against as long as they stayed at our winter-quarters. I shot a male on the lst of June, but had frequently seen this bird earlier.

Circus cyaneus (Linn.).

I saw the first Hen-Harrier on the 24th May, and one or more were almost daily seen as long as we remained at the Koo-ráy-i-ka. I shot two old males, one young male, and one female.

Syrnium uralense (Pall.).

We frequently saw a large $O w l$, which I have little doubt was of this species, sailing over the ship in the evenings whilst she was frozen up in winter-quarters; but it took care never to come within range of our guns.

Asio accipitinus (Pall.).

I twice saw the Short-eared Owl, once in lat. $66 \frac{1}{2}^{\circ}$, and the other time in lat. $67^{\circ}$, but failed to secure a specimen.

Nycrea scandiaca (Linn.).

I did not see the Snowy Owl on the wing, but had a very white specimen sent me in the flesh, which bad been caught in a fox-trap. In lat. $70 \frac{1}{2}^{\circ}$ the natives told me that this bird and the Willow-Grouse were the only species which wintered on the tundra.

\section{Podoces hendersoni, Hume.}

This remarkable bird has not yet been recorded from political Siberia, but occurs almost on the frontiers, in the Eastern Palæarctic region. When I was passing through Omsk, Professor Slofftzoff presented me with a skin of this bird, which had been shot by a shepherd on the Chor'-na Ear'-tish, or Black Irtish, a river which flows through Lake Saisan and joins the Ear'-tish near Semipalatinsk. The shepherd described it as 
very wild and difficult to approach, and said that he had chased it for a couple of days before he succeeded in securing it.

This specimen differs from Hume's description in having no spots on the head. Only a few of the feathers on the nape have slight indications of spots, almost like gold dust, at the tips. The plate of this bird in 'Lahore to Yarkand' (p. 244) is by no means a good one. The bar on the wing in my copy is coloured very pale blue, instead of pure white; and the conspicuous white feathers on the carpal joint are entirely concealed by the feathers of the breast.

Picoides tridactylus (Linn.).

Picus tridactylus, Linn. Syst. Nat. i. p. 177 (1766).

Apternus crissoleucus, Bonap. Consp. Vol. Zyg. p. 9 (1854), ex Brandt, MS. in Mus. Petrop.

On my arrival at the wintering-place of the 'Thames' on the Arctic circle, I found the Three-toed Woodpecker common in the pine-forests on both banks of the Koo-ray'-i-ka, and was assured by the sailors that it had frequently been seen there throughout the winter. I brought home seven skins of this bird, six of which are representative examples of the form $P$. crissoleucus (Bp.), in which the underparts are much whiter than usual, the feathers on the belly and under tail-coverts being very slightly barred with black, and the outside tail-feathers also displaying more white than in the common form. The seventh skin agrees exactly with skins of the usual colour in my collection from the Petchora, Archangel, and Norway. It seems doubtful whether $P$. crissoleucus be an Eastern form of $P$. tridactylus, or merely a very old bird of the latter species. I may remark that in my series of skins the yellow on the head of the male is more developed in the paler-coloured birds than in those more profusely barred, favouring the idea that the difference is one of age.

Sitta Europea, Linn.

Birds are very rare in the Siberian forests in winter. I have often silently threaded my way between the pines on snow-shoes for hours without hearing a note or seeing a feather. Then, perhaps, I should suddenly find myself in the [16] 
midst of a small party of Lapp-Tits. What few birds there are in these vast solitudes are very sociable. I generally found the Lapp-Tits accompanied by a pair of Pine-Grosbeaks, and occasionally by a pair of Nuthatches. The Nuthatch of the Yen-e-say' cannot be separated specifically from the common European form. It is undoubtedly a whiter form. The forehead is whiter, and the flanks are much less rufous. These paler forms are characteristic of Siberia, and have given rise to many new synonyms. Thus the Siberian form of Picus tridactylus has been called $P$. crissoleucus by Brandt, that of Parus cinctus P.grisescens by Dresser; and the pale form of Sitta europea is the $S$. uralensis of Lichtenstein, the $S$. asiatica of Gould, and the S. roseilia of Bonaparte.

Dresser, in his 'Birds of Europe,' describes the legs of $\mathbf{s}$. europea as "plumbeous grey," in contradistinction to those of S. casia, which he describes as "pale dull brown." This does not at all agree with my observations in Siberia. The following note was written on the spot, with several freshkilled birds of each of the two species referred to before me :"The Nuthatch and the Titmouse which are found here are remarkably alike in their general distribution of colour, but differ considerably in the bill and feet. The feet of the LappTitt are lead-colour, almost black. The bill of the Nuthatch is dark lead-colour above, and pale lead-colour below, almost the colour of the back." The feet, on the other hand, seem to have been painted with the same colouring matter as the under tail-coverts, and are pale chestnut-brown, with the soles a dirty yellow.

\section{Cuculus canorus, Linu.}

I first heard the Cuckoo on the 5th June, and shot a male a few days later. I did not myself hear this bird further north than $67^{\circ}$, but was assured that it was not unfrequent at Doodin'-ka, in lat. $69^{\circ}$, nearly at the limit of forest-growth.

Cuculus himalayanus, Vigors.

On the 15th of June a second species of Cuckoo presented himself, with an entirely different voice to our bird, a guttural and hollow-sounding hoo, not unlike the cry of the Hoopoe. This cry can be heard at a great distance, and is 
generally repeated two or three times in succession. The bird was very wild, and I only succeeded in shooting two of them, both females-one an old bird in grey plumage, the other in the red plumage of the first year. This Cuckoo is almost an exact miniature of our bird, though the bill is slightly larger than that of the common European Cuckoo, and the barring on the underparts somewhat more distinct. If it had not been for the difference in voice, I should have scarcely supposed it to be more than a small race of our bird. The wings measure $7 \cdot 6$ in.

Cuculus striatus, Drapiez.

"Cuculus striatus, Drapiez," Jerdon, B. Ind. i. p. 328.

"Cuculus optatus, Gould," Radde, Amurl. ii. p. 135.

In Dresser's exhaustive article on the Common Cuckoo in the 'Birds of Europe,' of which he has kindly lent me the proof sheets, he refers to the nearly allied species. Two of these come into my Sibcrian region, Cuculus optatus, Gould apud Radde, and Cuculus sparverioides, Vigors apud Schrenck. Dresser identifies $C$. optatus with $C$. himalayanus. In this I cannot agree with him. After comparing Jerdon's excellent description of the note of the Himalayan species with Radde's minute account of the note of the Amoor bird, I think we may positively state that C. optatus, Gould apud Radde, is not $C$. himalayanus, Vigors apud Jerdon. The dimensions given by Radde are much too large for those of $C$. himalayanus, and agree best with those of $C$. striatus. After examining the cuckoos in the British Museum, I do not feel much doubt that Radde's bird was a specimen of C. striatus.

Cuculus hyperythrus, Gould.

Von Schrenck gives an excellent figure of what he thinks, somewhat doubtfully, to be an immature male of Cuculus sparverioides, Vigors. I have two skins lately brought from Japan by Mr. Heywood Jones, which agree exactly with Schrenck's plate. They appear to me to be much too small for C. sparverioides; and I am inclined to identify both the Amoor and the Japan birds with the Cuculus hyperythrus of Gould, described by him in the P.Z.S. of 1856, p. 96, and figured in the 'Birds of Asia' (pt. 8). 


\section{Corvus corax, Linn.}

We occasionally noticed Ravens during almost the whole of our long sledge-journey; but at the Koo-ray'-i-ka they did not appear until the middle of May. After their arrival a day seldom passed without one or more being seen. They seemed to me to be less shy than Ravens usually are, and I had no difficulty in shooting half a dozen to skin. I was told, upon good authority, that in summer they are found as far north as the Russian fishermen go, about lat. $72^{\circ}$. I brought home eight skins of this bird with me. They varied in length of wing, from carpal joint, from $16 \cdot 2$ to $17 \cdot 2$ inches. The exposed portions of the bastard primary varied from 6 to 7 inches, and the distance from the end of the first primary to the end of the second primary from 3.3 to 4 inches, the bastard primary exceeding in length the end of the innermost secondaries.

\section{Convus cornix, Linn.}

During the whole of our long sledge-journey from Nishni Novgorod as far as Tomsk the Hooded Crow abounded on the road-sides; and in returning during the autumn I found it equally common on the banks of the various rivers which the steamer navigates between Tomsk and Tobolsk, and between the latter town and Tyu-main'. Indeed, so far as my observation goes, the whole of Russia and West Siberia may be described as a vast colony of Hooded Crows. East Siberia, on the other hand, is an equally vast colony of Carrion-Crows. From Kras-no-yarsk' to Yen-e-saisk' I saw nothing but the Carrion-Crow. Middendorff records the same on the Lay'-na, and eastwards to the sea of Okotsk; and southwards Prjevalsky (pronounced Psheval'sky) found it common in Mongolia. The distance between Tomsk and Kras-no-yarsk' is about 550 versts. As you travel eastwards from Tomsk for the first 200 versts the Hooded Crow only is to be seen. During the last 200 versts before reaching Kras-no-yarsk' the Carrion-Crow alone is found. In the intermediate 150 versts about one fourth of the Crows are thoroughbred Hoodies, one fourth are pure Carrion, and the remaining half are 
hybrids of every stage; mulattoes, quadroons, octoroons, and so on ad infinitum. The line of demarcation between the two species may be roughly taken at the meridian of Calcutta, extending north of Yen-e-saisk' along the valley of the Yene-say', and south of that town along the watershed of the Obb and the Yen-e-say'. That this state of things is not of recent origin is proved by the fact that it is recorded by Middendorff, who remarked the presence of hybrid Crows at Yen-e-saisk' as long ago as 1814 . Hybrids between $C$. corone and $C$. cornix occur occasionally in Scotland, on the Elbe, in Turkestan, and probably wherever both species occur. The fact that these hybrids present a series of every intermediate form between the two species is prima facie evidence of their fertility. I succeded, howerer, in getting positive evidence of this fact. On the 11th May, whilst the ground was still covered with six feet of snow, I found a pair of hybrid Crows in possession of a nest near the top of a pine tree. The nest contained one egg. On the 21 st I climbed up to the nest again, and found it to contain five eggs. Two of these I took. On the 31 st one egg was hatched, and the other two were chipped ready for hatching. On the 26th June I again climbed up to the nest, and found that one of the young birds had either died or flown. I took the other two and shot the female. She proved to be at least three parts Carrion-Crow. The feathers on the sides of the neck, and on the lower part of the breast and belly, are grey, with dark centres. I was unable to shoot the male; but I had on various occasions examined him through my binocular. He had more Hoodie blood in him than the female, having a very grey ring round the neck, and showing a good deal of grey on the breast and under the wings.

My total bag of Crows at the Ku-ray'-i-ka was three thoroughbred Hoodies (two males and a female), ten thoroughbred Carrions (nine males and one female), and fifteen hybrids (seven males and eight females). These figures, as far as they go, lead me to the conclusion that the female CarrionCrows were all breeding, away in the woods, so that I rarely got a shot at one, whereas the female hybrids were most of 
them barren, so that I was able to shoot as many of one sex as of the other. The following descriptions of these handsome birds may be worth recording :-

No. 161. The thoroughbred Hooded Crow of the Yene-say' has the wings, tail, head, throat (extending as far as the upper part of the breast), and thighs black. The rest of the body is ashy grey, slightly darker on the under tailcoverts. The upper tail-coverts begin grey, gradually become darker in the centre until they are only edged with grey, and finally become black as they join the tail. The axillaries are grey. The grey is much lighter than in Western-European birds, being almost as light as in Corvus capellanus of Sclater, from Persia. The latter bird, however, has a longer bill.

No. 181 can only be called a Hooded Crow. The grey is a shade darker than in the preceding, and the shafts of the grey feathers on the back are very dark.

No. 162 has traces of black on the centres of the feathers across the back, but perhaps not more than one might expect to find in an accidental variety.

No. 128. The grey on the back is very similar to the preceding; but the upper and under tail-coverts are so much darker than usual that I have no hesitation in saying that this bird is not thoroughbred.

No. $16 \pm$ has still more Carrion-Crow blood in its veins. All the feathers of the back are black, with grey edges. The axillaries and upper and under tail-coverts are nearly black. The breast and belly are much darker than usual.

No. 166 I take to be about half-bred. It differs from the latter bird in having more or less grey edgings to the feathers on the back between the shoulders, in having the feathers of the breast and belly broadly edged with grey, and in having more or less grey on the axillaries and under tailcoverts.

No. 141 is very similar to the preceding; but the grey edges to the feathers are less distinct.

Nos. $12,143,144,146,163,165,167$, and 168 are evidently the commonest form (possibly octoroons). They are black, with a band of grey feathers (many of them with black 
centres) extending round the neck, below the black head, across the shoulders, above the wings, and crossing the breast below the black throat.

Nos. 139 and 140 are nearly thoroughbred Carrion-Crows : but they show a little grey on each side of the neck, between the head and shoulders.

These hybrids average 13.2 inches in length of wing from carpal joint, varying from $12 \cdot 3$ to $13 \cdot 8$. The exposed portion of the first primary varies in length from 4.2 to $4 \cdot 8$ inches; and the distance from the end of the first primary to the end of the second primary averages $3 \cdot 3$, varying from $3 \cdot 1$ to $3 \cdot 6$.

My Yen-e-say' Carrion-Crows average 13.3 in length of wing from the carpal joint, varying from $12 \cdot 7$ to 14 inches. The exposed portion of the first primary varies in length from 4.3 to 5.2 ; and the distance from the end of the first primary to the end of the second primary averages $3 \cdot 4$, varying from 3 to $3 \cdot 9$.

Corvus corone, Linn.

I was disappointed not to find any bird which I could identify with any of the eastern forms of this species, such as $C$. orientalis or $C$. japonensis. Both $C$. corone and C. cornix appear to winter south of lat. $60^{\circ}$. When we arrived at the Arctic circle we were surprised to find a pair of black Crows frequenting the banks of the Koo-ray'-i-ka. The sailors called them Ravens, and assured me that they had wintered near the ship. I succeeded in shooting the male; but, with the exception that he is slightly larger than any other Carrion-Crow which I shot, I camnot find any point of difference. He measures 14 inches in length of wing. The exposed portion of the bastard primary is 4.5 ; and the distance from the end of the first primary to the end of the second primary is $3 \cdot 9$. The end of the bastard primary falls considerably short of the end of the innermost secondaries.

After leaving the Aretic circle both this and the preceding species rapidly became rarer. We saw the last Hooded Crow in lat. $69^{\circ}$, and the last Carrion-Crow in $69 \frac{1}{2}^{\circ}$, about the limit of forest-growth. 


\section{Corvus Frugilegus, Linn.}

As we sledged over the snow in March and April from Nishni Novgorod to Yen-e-saisk', we never by any chance saw a Rook amongst the Magpies, Ravens, Crows, or Jackdaws on the road-side. Nor did I meet with this bird within the Arctic circle; but I was informed, upon very good authority, that a pair had once been seen two stations south of Vareshin'-sky, about lat. $68 \frac{1}{2}^{\circ}$. On the return journey I kept a sharp look-out for the Rook, but did not see it until we were threading the labyrinth of the Toor'-a, a little to the east of Tyu-main'. Here large flocks of Rooks were feeding on the banks of the river.

Corvus monedula, Linn.

Jackdaws were common on the road-sides and in the villages through which we sledged as far as Tomsk, but became gradually rarer as we neared Kras-no-yarsk', and disappeared altogether at Yen-e-saisk'. Mr. Boiling told me that a stray bird of this species was occasionally seen at the latter town, but that he had not seen any further north.

Nucifraga caryocatactes (Linn.).

As we sledged down the Yen-e-say' in April we first saw the Nutcracker in lat. $64^{\circ}$; and from that time we rarely missed seeing these birds at the different stations where we stopped to change horses. When we reached the 'Thames' we found this bird quite common and remarkably tame. At one time I counted as many as eight in one tree together. They are wonderfully sociable birds. Whilst the sailors were working at the ship, cutting away the ice all round her, there were frequently two or three Nutcrackers in different parts of the rigging, apparently watching the operation with great interest. They seem to be well aware of the fact that offal and scraps of food of all kinds are always to be found in winter near the habitations of man. Their tameness was quite absurd. Sometimes the Ost-yak children shot one with a bow and arrow ; and occasionally one was caught by the dogs. On the bushes round the house they allowed us to approach within four or five feet of them, and when disturbed moved to the 
nearest tree with a peculiar slow undulating flight. I carefully preserved them, and fed them with the bodies of the birds I skinned, as I was anxious to secure a good series of their eggs. They treated me, however, in a most ungrateful manner. They continued to be abundant until about the 7 th of June, when the snow was pretty well melted from the ground. They then vanished altogether, and, with the exception of a couple of birds I picked up later, in full moult, I saw no more of them until they reappeared in flocks at various stations on the return journey. I offered considerable sums for a nest containing eggs ; but both the Russian peasants and the natives informed me that they liad never heard of any one who had seen the nest of a "Ve-roff'-ky," as they call this bird. They doubtless retire into the recesses of the forest to breed.

Pica rustica, Scop.

Magpies were very common as far as Yen-e-saisk', but disappeared further north, at about lat. $60^{\circ}$. I did not see any during the summer within the Arctic circle; but Mr. Ulemann, an exile from West Poland, and a very intelligent observer of birds, assured me that he saw a pair every year at Vareshin'-sky, in lat. $69^{\circ}$, and had occasionally seen one as far north as Doo-dink'-a, in lat. $69 \frac{1}{2}^{\circ}$.

Sturnus vulgaris, Linn.

I did not observe the Starling until we had almost reached Yen-e-saisk' on the return journey. At that town it was extremely abundant, for the most part in large flocks.

LaniUs Major, Pall.

This Shrike was very common on the roadsides as we drove from Yen-e-saisk' to Tomsk. It was very fond of perching on the telegraph-wires. It differs from $L$. excubitor in only showing one white bar across the wings. The white bases to the primaries, from the second to the ninth inclusive, extend for about half an inch beyond the wing-coverts; whilst in the secondaries the white bases are entirely concealed by the wing-coverts, or are absent altogetber. Russow, at the St. Petersburg Museum, told me that this is the common eastern 
form, that $L$. excubitor breeds near St. Petersburg, whilst L. major only passes through on emigration. It winters in Asia Minor. It does not appear to be a very clearly differentiated species. I have a skin from Asia Minor with the basal half of the eleventh quill white, whilst the tenth, twelfth, and succeeding quills scarcely show a trace of white at the base; and, curiously enough, this is the same in both wings. Birds like these may be intermediate forms; or, after my experience of the Crow, I should not be surprised to find that on the boundary line of their geographical distribution they occasionally, if not habitually, intermarry.

\section{Passer domesticus (Linn.).}

The common Sparrow abounded in all the towns and villages through which we sledged as far as Yen-e-saisk', and disappeared about lat. $60^{\circ}$. On the 16th of June a solitary pair appeared at the Koo-ray'-i-ka, the only occasion on which I met with this bird within the Arctic circle.

\section{Passer montanus (Linn.).}

Tne only place between Nishni Novgorod and Yen-esaisk' $^{\prime}$ where I observed the Tree-S parrow was at a little village about forty miles west of Kasan. In Yen-e-saisk' it was as abundant as the common Sparrow; but I did not meet with it further north.

\section{Pyrrhula major, Brehm.}

The very handsome large variety of the Bullfinch with the brick-red breast was very abundant wherever the road passed through forests as far as Yen-e-saisk'; but I did not meet with it afterwards, either in the Arctic circle, or on the return journey.

\section{Carpodacus erythrinus (Pall.).}

The Scarlet Bullfinch arrived on the Arctic circle on the 6 th of June, and was soon afterwards very abundant. I did not observe it further north than lat. $68^{\circ}$. Its cheerful little song was constantly heard. It did not require a great stretch of imagination to fancy it said "pleased to see' you." I only shot one male without the scarlet on the breast. Baron Maydell got this bird in the Tschuski Land. 
Corythus enucleator (Linn.).

We found the Pine-Grosbeak common in the forests on the Arctic circle in small parties on our arrival. When summer came they dispersed in the woods, and were very rarely seen. I did not observe them further north.

Fringilia montifringilla, Linn.

The Brambling arrived at our winter-quarters on the lst of June. I did not observe it further north than $69^{\circ}$.

Linota linaria (Linn.).

Linota exilipes (Coues).

At Yen-e-saisk' we found large flocks of Redpoles in the first week in April ; but they did not put in an appearance at the Koo-ray'-i-ka until the 28th of May. I obtained both these supposed species, and every possible intermediate form.

The young in first plumage (No. 943, shot in the valley of the Yen-e-say', in lat. $69^{\circ}$, on the 29 th July) differs from the adult birds in haviug the edgings of the feathers of the plumage generally, but especially of the wing-coverts and innermost secondaries, greyish buff, instead of pure white. The feathers on the breast, flanks, and under tail-coverts have a dark streak in the centre.

My series of these birds comprises forty carefully sclected skins, from Norway, the Petchora, and the Yen-c-say'. Twenty-two of these are males, and eighteen are females. Two skins, one of a male and the other of a female, both shot in April, show considerable remains of the buff colour on the head, back, wing-coverts, and inner secondaries, characteristic of the bird of the year. Other skins show traces of this buff colour on the head and back only.

These birds fly in such large flocks that one often gets a dozen or more at a shot. In selecting birds to skin I invariably chose all the birds showing red on the breast, rejecting a large proportion of those without red breasts; nevertheless only half the males in my collection show any red on the breast. So far as it goes, this fact supports the theory of Mr. Hancock, that the red breast is a sign of immaturity. Niy red-breasted birds rary considerably inter se. Four of 
them have only a tint of rose-colour on the breast and rump. Thrce of these were shot in April, and one in June. They may be taken as types of the supposed species $L$. exilipes. All the feathers, but especially those on the rump, the wingcoverts, the inner secondaries, and the inner web of the outside tail-feathers, are broadly margined with white. There are scarcely any dark centres to the feathers on the rump, and none on the under tail-coverts; and the underparts are specially white. Two males, without the red breast, have the same characters, but are more abraded in plumage, and show less of the white margin to the feathers. A skin dated 12th July has the feathers so abraded that the white rump, and the white margins to the feathers generally, have almost disappeared; but the under tail-coverts are pure white. A skin dated 13th of June, from Norway, may be taken as full summer plumage of this form. The white margins to the tailfeathers are very conspicuous; but the red on the breast is more developed, and the mealy appearance of the bird has suffered from the abrasion of the feathers. Two females may possibly belong to this form, one of them having unstreaked under tail-coverts, and the other an unstreaked rump; but neither of them shows the broad margins to the tail-feathers. Another skin, dated the Fth of April, has the unstreaked rump, but streaked under tail-coverts. The breast is very carmine for the alledged species L. exilipes; and this shin also wants the broad white margins to the tail-feathers; but, as it shows a good deal of the immature buff-colour on the upper parts, it may be a bird which has retained other marks of immaturity.

Four skins with richly carmine breasts, and traces of carmine on the rump, all shot in June, are representative examples of $L$. linaria in breeding-plumage. They bave all streaked rumps and under tail-coverts; but one of them has broad white edgings to the inner webs of the tail-feathers. In two other skins, one shot on the 28th of July and the other on the 2ud of August, the plumage is very abraded, and the carmine on the breast nearly lost. The remaining skins have no carmine on the breast. In all of these the 
white elgings to the tail-feathers are narrow. They have all striped under tail-coverts; and all but two have streaked rumps.

I am inclined to think that $L$. exilipes is the same species as $L$. linaria. I do not sec that it is even a good variety. So far as I can make out, the differences are only those of age, sex, and season. If they must be separated, I think the colour of the under tail-coverts is a better character to go upon than that of the rump. 'Five birds, all males, have larger bills than the rest. Four of these have streaked rumps and under tail-coverts, the fifth is the slightly immature bird previously mentioned as having been shot on the 7 th of April.

I found these birds common as far north as I went, $i$. $e$. lat. $71 \frac{1}{2}^{\circ}$.

\section{Emberiza pusilla, Pall.}

The arrival of birds in the Arctic regions is dependent, to a large extent, upon the arrival of summer, which comes suddenly with the breaking up of the ice on the river, and the general melting of the snow. Last year, summer was unusually late in Northern Asia. On the Arctic circle, in the valley of the Yen-e-say', the ice on the river began to break up on the 1st of June, and migratory birds arrived in great numbers. On the 7 th the Little Bunting arrived, in company with the Golden Plover and the Dark Thrush, nearly in the middle of the spring migration.

Before the snow, which was lying upon the ground to the depth of five or six feet up to the lst of Jume, had sufficiently melted to make the forests penetrable, the Little Bunting was extremely abundant, and its unobtrusive song was constantly heard. On the 23rd of June I found the first nest. I was on the south bank of the Kno-ray'-i-ka, and was scrambling through the forest down the hill towards my boat, amongst tangled underwood and fallen tree-trunks, rotten and mossgrown, when a Little Bunting started up out of the grass at my feet. It did not fly away, but flitted from branch to branch within six feet of me. I knew at once that it must have a nest; and in a quarter of a minute I found it, half

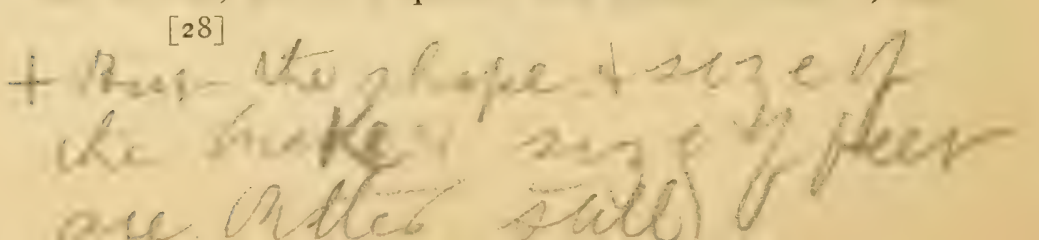


hidden in the grass and moss. It contained five cggs. The bird was still close to me; and I was obliged to leave the nest in order to get far enough from the bird, so as to aroid blowing it to pieces. It scemed a shame to shoot the poor little thing; but as the five eggs in the nest were the only authentic eggs of this species known to exist, it was absolutely necessary for their complete identification. The nest was nothing but a hole made in the dead leaves, moss, and grass, copiously and carefully lined with fine dead grass. The eggs were very handsome, almost exact miniatures of the eggs of the Corn-Bunting. The ground-colour is pale grey, with bold twisted blotches and irregular round spots of very dark grey, and equally large underlying shell-markings of paler grey. They measure $\frac{31}{40} \times \frac{22}{40}$ of an inch.

I took the second nest in the forest on the opposite bank of the Koo-ray'-i-ka on the 29th of June, containing three eggs. These egg are somewhat less, measuring $\frac{2}{4} \frac{8}{0} \times \frac{21}{40}$ of an inch. The colour is redder, being brown rather than grey, but the markings are similar. The nest was in a similar position, and the behaviour of the bird precisely the same. The third nest I took in lat. $67^{\circ}$, on the 30 th of June. The eggs, five in number, were slightly incubated. The markings are similar to those of the eggs in the two preceding nests; but the ground-colour is browner, being less olive than in the first nest, and less red than in the second. The nest was lined with reindeer-hair. The fourth nest contained six eggs, and was taken a few miles to the north of the preceding, on the 6 th of July. The eggs are intermediate in colour between those of the two nests last described. The character of the nest was similar to the last, but more sparingly lined with reindeer-hair. The tameness of the bird was the same in every instance.

The Little Bunting was common in the forest from the Arctic circle northwards, and afterwards on the tundra up to lat. $71^{\circ}$; but I did not observe it at Gol-cheek' ${ }^{\prime}$ a, in lat. $71 \frac{1}{2}^{\circ}$, nor upon the Brek'-off-sky islands. There are skins of this bird in the St.-Petersburg Museum, collected by Baron Maydell in the Tschuski Land. 
Eurberiza scheniclus, Linn.

The Reed-Bunting arrived on the Aretic circle on the 13th of June, and soon became very common. As we proceeded north we lost sight of this bird before we had quite reached the limit of forest-growth; but I got a sitting of its eggs in lat. $70 \frac{1}{2}^{\circ}$.

\section{Emberiza polaris, Midd.}

On the 9th of June, four days before the arrival of the Reed-Bunting, a smaller and darker-coloured Bunting appeared. It was very shy and skulking in its habits, and I only secured one specimen. I afterwards added a second to my collection. It appeared to be a comparatively rare and local bird. I did not find it anywhere except on the banks of the Koo-ray'-i-ka. I looked for it in vain on the other bank of the Yen-e-say', opposite the mouth of the Koo-ray'i-ka, a locality where the Reed-Bunting was extremely abundant. The following measurements of a male, compared with a male of the common bird from the same locality, show that it is considerably smaller than the European Reed-Bunting, with a proportionately slightly longer tail. The figures are inches and decimals.

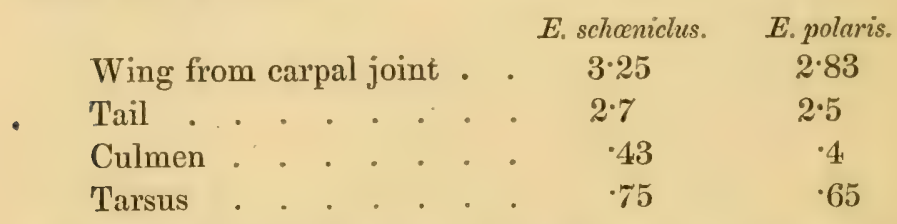

The distribution of colour in the two species is exactly the same, except that the margins of the feathers on the back, wing-coverts, and inner secondaries vary from rich chestnut to pale brown in the larger specics, and from blue-grey to white in the smaller species. This is specially conspicuous on the wing-coverts near the carpal joint. On the smaller bird there is a trace of chestnut in the middle of the back and on the inner secondaries.

So far as I know, the male of this bird has never been described before; but I think there can scarcely be a doubt that it is the male of the bird described by Middendorff as Emberiza 
polaris in his 'Sibirische Reise,' ii. p. 146. This bird was 'described from a female, obtained by Middendorff about three hundred miles to the north-cast of the locality where I procured my bird. He represents it as differing from the female of $E$. schœeniclus in almost precisely the same characters which I have pointed out above as distinguishing the two males.

Emberiza aureola, Pall.

I shot this very handsome and conspicuous bird for the first time on the Arctic circle on the 9th of June, but only occasionally saw it afterwards. This must be nearly its northern limit. On the return journey I shot it again at Yen-e-saisk', in lat. 58 , in the middle of August, with scarcely fledged young. There are skins of this bird in the St.-Petersburg Museum, collected by Baron Maydell in the Tschuski Land.

\section{Emberiza leucocephala, Gmel.}

I shot one solitary bird of the Pine-Bunting on the Arctic circle on the 13th of June, but did not meet with it again.

Emberiza rustica, Pall.

I did not meet with this bird until I reached lat. $62^{\circ}$, on my return journey.

Plectropianes nivalis (Linn.).

In crossing the great steppes of South-western Siberia, between Tyu-main' and 'Tomsk, we frequently came upon small flocks of Snow-Buntings. These birds seem to have no settled winter home; but during the cold weather they apparently live a roving gipsy life, wandering about in flocks, perpetually migrating northwards as fast as the frost and snow will let them, but continually forced to beat a retreat with every return of wintry weather. As we passed throngh Yen-e-saisk' early in April, we were told that the SnowBuntings had arrived just before us. When we reached the winter-quarters of the 'Thames,' on the 23rd of April, the sailors informed us that the Snow-Buntings had preceded us by a few days. Small flocks were constantly seen until the 7 th of June. We saw no more of them until we reached Golcheek $^{\prime}-\mathrm{a}$, where we were in their breeding-grounds. 


\section{Plectrophanes lapponicus (Linn.).}

The Lapland Bunting did not arrive at the winter-quarters of the 'Thames' until the 4th of June. It was breeding in great numbers on the tundra as far north as we went, $i . e$. lat. $71 \frac{1}{2}^{\circ}$.

Alauda arvensis, Linn.

The only Skylark I saw was one which I shot at our winterquarters on the 11th of June.

Otocorys ALPESTRis (Linn.).

The Shore-Lark was common on the Arctic circle from the 2nd to the 11th of June. After we had passed the limit of forest-growth, and had reached the tundra, it was again common as far north as we went.

Anthus gustavi, Swinhoe.

Anthus gustavi, Swinhoe, P. Z. S. 1863, pp. 90, 273.

Anthus batchianensis, G. R. Gray, Hand-l. of Birds, i. p. 251. no. 3642 (1869).

Anthus seebohmi, Dresser, Birds of Eur. pt. xlv. (1875).

It is seldom that the history of an obscure bird is so suddenly and completely worked out as has been the case with this species during the last two years. The Siberian Pipit was first described by Swinhoe in 1863 (loc. cit.), from specimens obtained at Amoy, in South China, on migration. In 1871 (P.Z.S. p. 366) he announced its identity with Anthus batchianensis, based by G. R. Gray on skins collected by Wallace in Batchian. In 1874 (Ibis, p. 442) he announced the capture of no less than fourteen of these birds at Chefoo, during the spring migration, and mentions having secn one skin sent from Lake Baikal by Dr. Dybowsky. In 1875 Harvie Brown and I found it breeding in the valley of the Petchora, about lat. 67 $\frac{1}{2}$ (Ibis, 1876, p. 120). Our skins were submitted to Dresser, who, belicving the species to be undescribed, included it as a new species in the "Birds of Europe' as Anthus seebohmi. In 1876 Finsch and Brehm procured a specimen in the valley of the $\mathrm{Obb}$, a little to the north of the Arctic circle (Ibis, 18\%7, p. 58). In the same number of 'The Ibis' I had the honour, I will not say the 
pleasure, of pointing out the fact that Anthus seebohmi of Dresser was identical with Anthus gustavi of Swinhoe. Just before leaving for Siberia I was, by the kindness of Dr. Brüggemann, put in possession of the facts that Anthus gustavi had been procured in winter at Manilla (Brüggemann, Abhandl. Ver. Bremen, v. p. 67), Celebes (Brüggemann, loc. cit.; Walden, Tr. Z. S. viii. p. 117), Bormeo, and Negros (fide skins in the British Museum).

During the arrival of migratory birds on the Arctic circle in the valley of the Yen-e-say', I naturally kept a sharp lookout for this interesting species, and was delighted on the 23rd of June to hear its peculiar and familiar song, and to shoot a fine male. On the 15 th of $\mathrm{July}$, in lat. $70 \frac{1}{2}^{\circ}$, I met with this bird breeding, and obtained a sitting of its eggs. On the 26th of July, on my return journey, in about the same latitude, I found it breeding in considerable numbers, and secured eight specimens more.

In the Museum of St. Petersburg I had the pleasure of identifying skins of this species collected by Baron Maydell in the Tschuski Land, north of Kamtchatka, and on Behring Isle, to the east of that peninsula, collected by Wossnessensky; so that it would appear that the geographical distribution of this Pjpit is almost the same as that of Phylloscopus borealis.

\section{Anthus cervinus, Pall.}

The Red-throated Pipit was first seen on the banks of the Koo-ray'-i-ka on the 6th of June. One of the birds which I shot on that day was in winter plumage, with scarcely a trace of vinous on the throat; and I entered it in my journal as the sole example of Anthus pratensis which I met with in the valley of the Yen-e-say'; but in St. Petersburg Russow pointed out to me the difference between the plumage of Anthus pratensis and the winter plumage of $A$. cervinus. In the latter bird the central large under tail-covert has a dark streak up the middle near the shaft. I have examined the whole of my large series of these birds from Norway, Russia, and Siberia, and winter skins of A. cervinus from Asia Minor 
and China, and find that in every case where the large under tail-covert has not been shot away this distinction holds good. This bird breeds in considerable numbers on the tundra as far north as we went. There is a great variation in the colours of the eggs in the same nest, some being much darker than others. There are skins of this bird in the Museum at St. Petersburg, collected by Baron Maydell in the Tschuski Land.

Anthus richard, Vieill.

Richard's Pipit must breed in great numbers on the extensive mearlow-lands which stretch away for miles from Yen-esaisk' on the banks of the river. I found it common there in the middle of August, and shot both adult birds in full moult and young in first plumage. This bird has a liabit of hovering over the ground almost exactly like a Kestrel.

Anthus trivialis (Linn.).

I did not meet with the Tree-Pipit until I reached lat. $62^{\circ}$ on my return journey.

Motacilla alba, Linn.

Motacilla alba, Linn. Syst. Nat. i. p. 331 (1766).

Motacilla dukhunensis, Sykes, P. Z. S. 1832, p. 91.

Motacilla baicalensis, Swinhoe, P. Z. S. 1871, p. 363.

I think there can be no doubt that $M$. alba and $M$. dukhunensis are the same species. The only difference seems to be in the amount of white on the wing-coverts. M. alba has dark grey or black wing-coverts, more or less broadly edged with white. In $M$. dukhunensis the inside half of each wing-covert is the same as in $M$. alba; but the outside half is entirely white, making the wing-corerts, as they lie on the wing overlapping each other, an entirely white mass. This latter form seems to be confined to Siberia and India; but as in both these countries a complete series of intermediate forms occur also, we cannot consider the eastern form more than a variety. The amount of white on the wing-coverts of many of the species in this genus, and in some of them the amount of white on the secondaries, varies so much, that if we were to admit it as a specific cha- 
racter we should at once more than double the number of supposed species.

In the valley of the Yen-c-say' both varieties were equally common. I only found the extreme white-winged form among the males.

This Wagtail was the first thin-billed bird to arrive on the Aretic circle in any numbers. The first break up of the ice on the Ist of June was the signal of its appearance. I found it as far north as we went, $i$. e. lat. $71 \frac{1}{2}^{\circ}$.

The geographical distribution of this bird is very curious. As Middendorff did not find it, we may take the watershed between the Yen-e-say' and the Lay'-na as its eastern boundary, whence it extends westwards as far as the Atlantic on the continent of Europe, but only appears accidentally in the British Isles. As you ascend the Yen-e-say' from the Aretic circle, this bird abounds on the banks of the river until you near Yen-e-saisk' (about lat. 59 ${ }^{\circ}$ ), when suddenly it disappear's, and its place is taken by $\boldsymbol{M}$. personata. From Yen-esaisk' to Kras-no-yarsk', and westwards until you cross the meridian of Calcutta, $M$. personata abounds, after which, across Siberia and Europe, you find no white Wagtail but M. alba.

There appears, however, to be a colony of $M$. alba still further to the east. Middendorff had a skin sent him from Birjussa, about halfway between Yen-e-saisk' and Lake Bai$\mathrm{kal}$; and there is no doubt that it is a common bird in the neighbourhood of that lake, as skins collected in that locality by Dr. Dybowsky are not rare in collections. From this colony these birds migrate in great numbers across Mongolia and the extreme west of China, and doubtless find their way thence to India.

\section{Motacilla personata, Gould.}

This is a very well-marked species, differing from $M$. alba in having the black on the breast confluent with the black on the neck. Well-marked examples show even more white on the wing-coverts than in the most marked $M$. alba, var. dukhunensis, whilst others are similar in this respect to typical
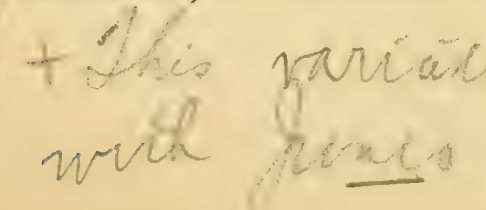
examples of the European form of $M$. alba-an additional proof that this character cannot be deemed specific in the Wagtails. I did not meet with this bird until my return journey. The particulars of its geographical distribution in Siberia, so far as I lad an opportunity of observing it, are given under the head of $M$. alba.

\section{Motacilla ocularis, Swinhoe.}

Motacilla ocularis, Swinhoe, P. Z. S. 1863, p. 17.

Motacilla alba, Linn., var. lugens, Ill. Midd. Sib. Reise, ii. p. 166 (185I, nec Ill. nec Temm.).

Motacilla baicalensis, var. temporalis, Swinhoe, P. Z. S. 1871, p. 363.

In the Museum at St. Petersburg I had an opportunity of examining several skins collected by Middendorff in North and East Siberia labelled Motacilla lugens. They all proved on examination to be Motacilla ocularis, a grey-backed pied Wagtail, with a black patch on the hind crown extending to the nape, and another on the throat and breast. It differs from Motacilla alba in having a narrow black line extending from the centre of the black patch on the head, and passing through the eyes to the base of the bill. In the same museum were skins of $M$. ocularis from the Amoor, collected by Schrenck, from Mongolia, collected by Prjeralski, and from the Tschuski Land, collected by Maydell. I did not meet with this species on the Yen-e-say'; and probably the watershed between that river and the Lay'-na is its western boundary.

Motacilla amurensis, sp. nov. (Plate IX.)

Motacilla alba, var. lugens, v. Schrenck, Amur-Lande, i. p. 338 .

In the present condition of ornithological literature, loaded with synonyms, any one who adds a name to the almost exhaustless list is guilty of a crime; but where the species froves to have been undescribed before, his fellow ornithologists will admit that he has a right to plead "cxtenuating circumstances." I am afraid I shall be unable to complete $\mathrm{my}$ list of Siberian Wagtails without describing a slim in $\mathrm{my}$ 
collection, obtained through Schlüter of Halle, dated 14th April, 1876, from the Gulf of Abrek, in the Sea of Japan, labelled Motacilla ocularis ơ. The head, neck, and back are black, gradually fading into grey on the rump, which becomes black again on the upper tail-coverts. The throat, breast, and a line through the eye are also black. Forehead and cheeks, and a line behind the eye and on the side of the neck, white. Shoulders grey. Wing-coverts white. Inner secondaries broadly edged with white on the outside web. Primaries and secondaries broadly edged with white near the base of the inner web.

This bird is undoubtedly the Motacilla alba, var. lugens, of Schrenck, who describes it as common in the Amoor, and considers it an intermediate form between $M$. japonica and M. ocularis. There seems to be no alternative but either to describe it as a new species, or to regard it as a hybrid between the two species just named. I have preferred the former course as the least evil of the two. From M. ocularis it may at once be distinguished by its black back, and from $M$. japonica by its grey secondaries.

In Dresser's collection is a skin of this bird from Japan, a male, collected by Whitely, 17th April, 1865; and I have a skin collected by Wossnessensky on the 23rd of April, 1845, upon "Oorogan Island," possibly either one of the Kurile or one of the Aleutian Isles.

Motacilla alboides, Hodgs.

Motacilla alboides, Hodgson, As. Res. xix. p. 191 (1836).

Motacilla leucopsis, Gould, P. Z. S. 1837, p. 78.

Motacilla luzoniensis, auctt. nec Scop.

Motacilla alba, var. paradoxa, Schrenck, Reis. u. Forsch. im Amur-Lande, i. p. 341 (1860).

Motacilla felix, Swinhoe, P. Z. S. 1870, p. 121.

There are five species of white Wagtails found in India. Two of these are resident species, $M$. maderaspatana, hereafter alluded to, and $M$. hodgsoni, which may be described as a black-backed $M$. personata. Of the remaining three we have already disposed of the breeding-places of two, $\boldsymbol{M}$. personata 
and $M$. alba, or, as the Indian bird is generally called, $M$. dukhunensis. The remaining species, M.luzoniensis, iulabits the easteru plaius of India in winter. Swinhoe has clearly pointed out (P.Z.S. 1870, p. 120) that this bird has no right to the name luzoniensis. Scopoli founds his name upon "La Bergeronette à collier de l'île de Luçon" of Sonnerat, in his 'Voyage à la Nouvelle Guinée,' vol. i. p. 61, pl. 29. Somnerat describes the colour of the back as "gris de cendre," and figures a Wagtail with a grey back, very white wing-coverts, a white forehead, cheeks, and throat, but with a gorget of black on the breast confluent with the black on the neck and head. It might represent a female of $M$. hodlgsoni, or a male of $M$. personata in winter plumage; but inasmuch as no white Wagtail has been recorded since from this locality, I think we are perfectly justified in cutting the Gordian knot by ignoring the name altogether.

M. alboides is in summer a black-backed Wagtail with a black breast. The forehead is white, and a white band separates the black on the head and neck from the black on the breast, as in $M$. alba; but besides the black back, it differs from $M$. alba in never having the throat black. In winter the back is more or less grey, but the shoulders remain black.

I think there can be no doubt whatever that this bird is the Motacilla alba, var. paradoxa of Schrenck, who figures it and describes it as breeding in the Amoor-land.

Motacilla Lugens, Temm. et Schl.

Motacilla lugens, Temm. et Schl. Fauna Japonica, Aves, p. 60, pl. 25 (1850).

Motacilla japonica, Swinhoe, Ibis, 1863, p. 309 ; P. Z. S. 1863, p. 275.

After having just stated that the amount of white on the wing of a Wagtail cannot be considered a specific character, it may appear somewhat paradoxical to assert that the principal and most trustworthy character of this bird is the great amount of white on the wing. In this species, however, it is not only the wing-coverts, but the secondaries and some of 
the primaries which are more or less white. M. lugens may always be recognized by some of the secondaries being white across both webs, and frequently one or two of them are pure white throughont. The amount of white on the primaries varies very much. In summer this species comes very near M. maderaspatana, having a black back, and the white on the head being coufined to the forehead and supercilium. On the average $M$. lugens is a smaller bird than $M$. maderaspatana; but large skins of the former species measure more in length of wing than small skins of the latter species. In $M$. maderaspatana the black on the head comes down in a peak to the base of the bill. M. lugens has a pure white forehead, the black on the head not approaching within half an inch of the base of the bill. This appears, however, not to be a perfectly stable character, as I have a skin in my collection of the last-named species from Hakodate, in which the black of the forehead comes down in a peak to the base of the bill, as though a not very remote ancestor of this individual had migrated to India instead of China for the winter, and had there intermarried with one of his cousins, as our friends theCrows are in the habit of doing. In winter M. lugens comes very near to M. ocularis. Both species have then grey backs, black heads, a gorget of black on the throat, and a black line passing from the base of the bill through the eye, and joining the black at the back of the neck. M. ocularis is, however, a grey-backed Wagtail, both summer and winter, and has a grey shouldex; whereas $M$. lugens loses the black on the back in winter, but retains it on the shoulder the whole year. Independently of these minor differences, the amount of white on the primaries and secondaries of $M$. lugens serves to distinguish it easily at all seasons of the year.

The geographical distribution of this species, so far as I have been able to ascertain it, from the examination of wellauthenticated skins, appears to range from Kamtchatka to Japan in summer, and in winter along the coast of China and the opposite islands, Formosa, \&c. I can find no evidence of its having been found further west. The skins in Dresser's collcetion, collected by Severtzoff in 'Turkestan (Ibis, 1876, 
p. 177), are $M$. hodgsoni. Middendorff's skins of $M$. lugens in the St.-Petersburg Museum are M.ocularis. In the same museum there is, however, a fine series of skins of the true $M$. lugens from Kamtchatka.

The synonymy of this bird, simple as it appears, is most bewildering. We have the authority of Mr. Hume ('Stray Feathers,' v. p. 434) for the assertion that, in the opinion of Professor Alfred Newton, "nomenclature bears the same relation to real natural history that rat-hunting does to real sport." Be this as it may, I do not know any one fonder of a "rat-hunt" of this kind than Professor Newton. In his article on the Pied Wagtail, in his new edition of Yarrell's 'British Birds,' we have an excellent résumé of a day's " rathunting." The first rat he starts is Motacilla lugubris, Pallas, and after ruming it through the fourth and third parts of Temminck's 'Manual of Ornithology, he finally loses the scent in the first part in 1820 (ed. 2, p. 253). The description here given being that of a bird which, in Professor Newton's opinion, is "unquestionably identical" with the British Pied Wagtail, that bird becomes $M$. lugubris, Pallas, apud Temminck; and since there is no evidence that Pallas ever gave the name of $M$. lugubris to any Wagtail, our British bird becomes M. lugubris, Temminck. The next "rat" that Professor Newton starts is M. lugens, Illig. This, he tells us in a footnote (loc. cit.), he chased as far back as 1850, where he suddenly lost the scent in the 'Fauna Japonica.' I must confess that my attempts to run down this animal have been still less successful. I started it in Oustalet's 'Oiseaux de la Chine' (p. 300), where I was at once tripped up by two errors ("F. Jap. Aves, 25," should read " F. Jap. Aves, p. 60, pl. 25 "; and "Swinh. (1860) 357," should read "Swinh. Ibis, 1860, p. 357 "). I picked up the scent again in the P.Z.S. 1870, p. 130, and stumbied on two more errors ("P.Z.S. 1863, p. 17," ought to be "P. Z. S. 1863, p. 275," and "Ibis, 1863, p. 85," ought to be "Ibis, 1863, p. 309"). Recovering myself, I pursued the trail through Schrenck's 'Amur-Lande,' 1860, with only a slight mishap (the page in Pall. Zoogr. RossoAsiat. i. intended to be referred to is 507 , not 307 ), and I [40] 
lost the scent altogether' in Middendorft's 'Sibiriselıc Reise,' p. 166 (1851). Since Professor Newton has not been able to kill this rat, as, I think, we may fairly infer from the footnote already referred to (Newton's 'Yarrell,' i. p. 541), I am driven to the conclusion that "lugens, Ill.," and "lugubris, Pall.," quoted by Middendorff, are both myths. My next attempt was to try aud catch a M. Tugens of Pallas, or of any body else. I had nearly as many stumbles in this as-in the previous runs. In the 'Fauna Japonica' Schlegel gives a reference to Temminck's 'Manuel' as " part iii. p. 620," which ought to be read "part iv. p. 620," an error which I found he had previously made in his 'Rev. Crit. des Ois. d'Eur.' p. 68. In spite of these difficulties I did not lose the seent until 1832, where, so far as I have been able to trace it, $M$. lugens, Pallas, appear's for the first time in Kittlitz's ' Kupfurtuf fin zur Naturgeschichte der Vögel,' p. 16, pl. 21. fig. 1, from Kamtchatia.

From this peninsula there is fortunately a series of skins in the St.-Petersburg. Iusemm, which I had an opportunity of examining, and which I identified as M. lugens of Temm. \& Sehl. Fittlitz describes his bird as the commonest summer bird in ¿...hichatlia, and remarks that in autumn it has a white throat, bounded bencath by black, and an ash-grey back. The description is rery meagre, and the plate of the bird in brecding-dress represents a state of plumage which I have not seen. The throat is in full summer plumage, i.e. black to the base of the bill, but the cheeks remain in winter plumage. A reference to the exeellent plate of $\boldsymbol{M}$. luyens in the 'Fauna Japonica' (pl. 25) will show that in full breedingplumage the black on the throat extends up to, and forms one mass with, the black line through the eye.

We must admit that the description and also the plate of $M$. lugens, Pallas, apud Kittlitz, are scarcely as satisfactory as we could have wished upon which to found a species; but as the Japancse bird is the only Pied Wagtail hitherto found in Kamtchatlia, there is at least a strong probability that Kittlitz's name refers to this bird. There is no evidence to prove that Pallas ever named a bird M. lugens. M. lugens, 
Pallas, apud T'emminck (Man. d'Orn. iv. p. 620), is identified with M. lugubris (Man. d'Orn. iii.p. 175), which undoubtedly includes the Japanese bird. Our bird therefore stands as M. lugens, probably of Pallas apud Kittlitz, partly of Pallas apud Temminck, certainly of Temminck and Schlegel. Since it only involves a change of authority and not of name, this seems to me to be a case in which we may safely avail ourselves of the strict letter of the rules of nomenclature, and call our bird Motacilla lugens, Temm. et Schl., on the ground that this name was "clearly defined" for the first time in the 'Fauna Japonica,'-rejecting also Swinhoe's name of $M$. japonica, as having been subsequently given, under the erroneous impression that the name $M$. lugens "had already been applied to the very different western species" (vide P. Z.S. 1870 , p. 130).

It is somewhat remarkable that such an eventful day's " rathunting" should end without a kill, that of the three rats started (M. luyubris, Pall., M. lugens, Pall., and M. lugens, Illig.) every one should be run to earth, and that there is the strongest probability that all the three "rats" are phantom rats, myths. It is still more remarkable that the references to these names should be quoted with so many blunders; but perhaps the most remarkable circumstance of all is, that Professor Newton, in the note already twice referred to, should have "made another complication" by starting a fourth phantom rat, $M$. lugens, Illig. apud Schlegel*.

Motacilla flava, Linn.

I shot a solitary example of the Blue-headed Wagtail with the white eye-stripe on the 11th June, on the Arctic circle. This bird had probably accidentally migrated with the large flocks of $M$. viridis beyond his usual latitude.

* Since the above was written, Professor Newton has pointed out to me that in all probability it was Bonnparte who first ascribed the name "lugens" to Illiger in 1850 , the correctness of which statement Middendorff no doubt took for granted in 1851. Professor Newton desires to correct his footnote (Newton's 'Yarrell,' i. p. 541) as follows:-“. . . . and the Japanese form therein appeared as ' $M$. lugens,' a name ascribed by several writers, and amongst them Bonaparte (Consp. Ar. i. p. 250), to Illiger; but whether. ...."

[42] 
Motacilla viridis, Gmel.

The Grey-headed Wagtail arrived in flocks on the Aretic circle on the 5th of June, and soon became extremely abundant. It does not scem to extend its range beyond the limit of forest.growth, and disappeared about lat. $69^{\circ}$.

Motacilla citreola, Pall.

This beautiful bird was the first of the yellow Wagtails to arrive at our winter-quarters. I secured the first example on the 4 th of June, and afterwards found it very abundant on the tundra as far north as we went.

Motacilla melanope (Pall.).

One solitary example of the Grey Wagtail foll to my gun on the 6th of June. As this is the first time that this bird has occurred within the Arctic circle, so far as I am aware, it may be looked upon as an accidental occurrence. I may remark that my bird, with a tail measuring 3.75 inches, is intermediate in form between the eastern and western varieties, 
Ampelis garrulus, Linn.

On the 14th of June I recognized the note and caught a distant sight of a small flock of about half a dozen Waxwings; but the forest was so much flooded that I was unable to do more than watch the birds through my binocular.

Parus ater, Linn.

I did not meet with the Coal-Tit until I reached Yen-esaisk' on the return journey.

Parus major, Linn.

The Great Tit is a winter resident in the whole of South Siberia; and at various villages on the journey as far north as Yen-e-saisk' it was frequently seen. I did not observe it further north.

Parus palustris, Linn., subsp. camtchatkensis, Bon.

The only time that I met with a Marsh-Tit was on the 12th May. I only saw one pair, in company with a small party of Laps Tits. They certainly belong to the northeastern form, with grey rather than brom backs, and with 
the black on the head extending far down the back. I cannot distinguish a Yen-e-say' skin from others from Irkutsk and Archangel. It scems to me impossible to allow specific rank to the arctic and subarctic forms of P.palustris, and I think they ought to figure as subspecies only-P.palustris, subspecics borealis, and $P$. palustris, subspecies camtchatkensis.

Parus cincrus, Bodd., subsp. grisescens, Sharpe et Dresser.

I found the Lapp Tit tolerably common in the forests on our arrival on the Aretic circle. It was seldom that I made a round on snow-shoes in the forest without falling in with a small flock of these birds. I did not, however, observe them further north. I brought home a very large series. They agree with skins from Lake Baical in being much less rusty on the flanks than specinens from Europe usually are. They vary considerably inter se; and it would be easy to make a series from the Norwegian bird, through Archangel and Petchora skins, to the extreme Siberian form. My Yen-esay' skins certainly belong to the Parus grisescens of Sharpe and Dresser; but the authors of that title would now, I believe, scarcely claim specific rank for the bird they described.

Turdus pilaris, Linn.

The Fieldfare arrived at the Aretic circle on the 8th of June, and soon became very abundant. I took several nests with eggs during the first week in July. It seemed to be generally distributed over the country, brecding alone or in small parties, and not in the large colonies which are so frequently met with in Norway. The call-note of this bird, a loose tsik-tsak, was almost constantly to be heard; but the song seemed to be confined to the pairing-season. It is a low and not particularly melodious warble, and is generally commenced when the bird is on the wing. The last nest of the Fieldfare which I found was in lat. $69^{\circ}$, on the tundra. Here the bird was breeding on the ground under the edge of a cliff, in a situation such as a Ring-Ouzel might have chosen. I did not see the Fieldfare further north than lat. $70 \frac{1}{2}^{\circ}$; but $\mathrm{I}$ shot them as far south as Yen-c-saisk ${ }^{\prime}$, in lat. $58^{\circ}$, 
where they appeared to have been breeding, as it was only the middle of August.

\section{Turdus iliacus, Linn.}

I shot the first Redwing on the 5th of June. It appears to arrive earliex than the Fieldfare, and to go further north. On the Aretic circle it built its nest in the wllows and birches, but generally nearer the ground than the Fieldfare usually does. In lat. $71^{\circ}$ the Redwing was still common and breeding on the ground, generally on a sloping bank. I did not see it further north.

\section{Turdus dubius, Bechst.}

The first Thrush to arrive at the Arctic circle was this species-the Dusky Thrush (T. fuscatus of Pallas). Small parties of it arrived on the 4th of June, and were to be found feeding on the steep banks where the sun had melted the snow. Their call-note reminded me of that of the Redwing. During the next week they were very plentiful, and I began anxiously to look out for their nests; but within a fortnight after their arrival they had all disappeared, and I saw no more of them until the 12th of July, during our voyage down the river. On this day we cast anchor for a few hours in lat. $69^{\circ}$, and I went on shore to explore for the first time a Siberian tundra. I elimbed up the steep bank, and found myself in a wild desolate-looking country, full of lakes, swamps, and rivers, in some places a dead flat, in others undulating, and even hilly, brilliant with gay flowers, swarming with mosquitoes, and full of birds. In sheltered places dwarf willows and crecping-birches were growing, and (because we were only some fifty versts from the forests) here and there a few stunted larches. Winding through the tundra was the bed of a river, now nothing but a small deep valley, forming a chain of isolated lakes and pools. This river-bed bears the name of the dried-up Doo-din'-ka, and is about fifty rersts to the north-west of the real river Doo-din'-ka. On some of the northern slopes large patches of snow were still lying. Most of the birds evidently had young: I found myself generally the centre of attraction of a little crowd of birds 
uttering their various alarm-notes as they flew round or waited on some shrub or plant with their bills full of mosquitocs, anxious to feed their young as soon as I was out of their way. As I was returning to the shore, and descending a steep sloping bank covered with patches of dwarf birch and willow, overlooking a flat willow-swamp which evidently once formed a little delta at the mouth of the dried-up Doo-din'-ka, my attention was attracted by a pair of Dusky Thrushes loudly proclaiming the vicinity of their nest. I shot one of them, and, after a diligent seareh of half an hour, found the nest in the fork of a willow bush level with the ground. It was exactly like the nest of a Fieldfare, lined with dried grass, and contained, alas! five young birds about a week old.

At noon we weighed anchor; but at midnight it was blowing such a stiff gale that we were afrair to round the "broad nose " of Tol-stan-os' in the 'Ibis ;' so we cast anchor under the lee of the mud cliff's of the Yen-e-say', and I again went on shore. In some places the cliffs were very steep, and were naked mud or elay. In others the slope was more gradual, and was covered with mud and alder bushes. Among these bushes I found the Dusky Thrush again breeding, but was only able to find one nest with five nearly fledged young. The nest was placed, as before, in the fork of a willow, level with the ground. This was the last time that I saw this species of Thrush.

There is considerable variation in the colour of the skins of this species which I brought from the Yen-e-say', especially in the amount of black on the breast and red on the upper plumage. Some specimens have more or less rufous on the tail-feathers, approaching T. naumanni. One male in particular has scarcely any red tinge in the plumage, and has even grey instead of chestnut axillaries. The young in nestling plumage differ from the young of $T$. pilaris, $T$. iliacus, $T$. obscurus, and $T$. atrigularis, in having more buff on the wing and less buff on the breast.

Turdus obscurus, Gm.

During the first week of June the forests rere practically 
impassable. The deep snow was in process of melting, and too soft to bear the weight even when distributed over a pair of snow-shocs each measuring 4 fect 6 inches long and 10 inches wirle. On some of the stecper slopes exposed to the south small oases of bare ground were to be found. One of these, close behind my quarters, thinly covered orer with bushes, was a very prolific hunting-gronind for me during the spring migration. On this picee of ground, on the fth of June, I had the pleasure of shooting my first brace of Dark Thirushes (the Turdus pullens of Pallas, lut not the Turdus pullidus of (Gmelin). A couple of days afterwards I shot two mole on the same ground. As soon as the forests were passable I made daily rambles, and almost always heard the song of this bird. Turdus dubius had gone further north to breed; but this species was evidently stopping and making preparations to build its nest. This Thrush is a very poor songster, but he has a splendid voice. He warbles two or three clear rich notes, as mellow as those of a blackbird. He stops; his song is finished; and you hear no more for a minute, when the same brilliant prelude is repeated. On the 2\%t? of June I had the good luck to take the nest of this bird. It was placed upon a horizontal branch of a somewhat slender spruce, about fifteen feet from the ground. The female flew off as I approached the tree. I shot her, and soon had the nest with fire eggs in my hand. The nest is carefully made, neatly lined with mud and afterwards with dry grass. The eggs rescmble small but riehly marked Blackbird's eggs. I did not meet with this interesting 'Thrush surther nortit than the Arctic circle; but on my return journey, in lat. $66^{\circ}$, on the $3 \mathrm{rd}$ of August (and afterwards in lat $63^{\circ}$, on the 6th of Arigust), I shot the youmg in first plumage, with spotted backs and spotted breasts. One of these skins will be figured in Dresser's 'Birds of Europe.'

Turdus sibiricus, Pallas.

Whilst the remains of the ice were still straggling down the Yen-e-say' I occasionally caught a hasty glance at a dark-coloured Thrush with a very conspicuous white eychow; 
but I did not suceed in shooting one until the 19th of June It was feeling amongst the dead leares on the ground in a dense birch plantation. It proved to be a fine male in adult plumage. I made the following memorandum of the colours of the soft parts:-"Bill black. Iris dark hazel. Pupil blue-black. Legs very light brown, yellower at the back of the tarsus and on the soles of the fect." In lat. $68^{\circ}$ my companion assured me that he saw one of these very handsome birds on the wing; but I did not observe it myself after we left the Koo-ray'-i-ka, nor did I observe it at all on the return journey. It seems to be a very shy and wary bird, and it is evidently a very rare Thrush in the valley of the Yen-e-say'. Middendorifi docs not mention it; but I heard of it from a Polish exile at Toor-o-kitusk' as the Chor'-noi drohzd, or Black Thrush.

Turdus atrigularis, T'emm.

I did not meet with the Black-throated Thrush until the 6th of August, in lat. $63^{\circ}$, when I shot two birds in first plumage, which puzzled me. Two days later, in lat. $61 \frac{1}{2}^{\circ}$; I sccured a third young bird, and was fortmate cnough to obtain the adult female also. The chestnut colour of the wing-lining and axillaries of the young of this species serve to distinguish it from the young of $T$. piluris and $T$. obscurus. In the young of $T$. iliacus the chestuut of the wing-lining and axillaries is much deeper in colour, and extends onto the flanks, whilst it is scarcely perceptible on the under tailcoverts.

Rutichla phenicurus (Limn.).

My sole authority for including the Common Redstart among the birds of the Yen-e-say' is a fine skin of a young Redstart in first plumage, which I shot on the 3rd of August in lat. $66^{\circ}$. The plumage of this skin agrees exactly with that of the young in first plumage of our bird; and since it was found by Harvie Brown and myself in the valley of the Petchora in about the same latitude, I see no reason for suspecting my Yen-e-say' bird to be the young of any other allied species, though it has not hitherto been recorded from so far cast. 
Cyanecula suecica (Linn.).

I found the Blue-throated Warbler very common in the valley of the Yen-e-say'. It was amongst the carliest insecteating birds to arrive at our winter-quarters. I shot several on the 5 th of June. For a week or two they were very common; but as the snow on the tundra melted they gradually left us, only a few remaining to breed. I lost sight of the Blue-throat in lat. $71^{\circ}$.

Nemura cyanura (Pall.).

Curiously enough the first Warbler I shot on the Yene-say' was the Blue-rumped Warbler. It was, of course, only an accidental straggler, who had strayed away from his companions and reached the Aretic circle before his time. It was the 21st of May, a bitterly cold day, no sunshine, a sou'-west wind, but nevertheless a keen frost. I did not turn out in the morning; but in the afternoon I put on my snowshoes and had a round through the forest. There was hardly a bird to be seen; but as I was returning to the ship I canght sight of a little bird flitting about from tree to tree, apparently seeking insects on the trunks below the level of the surface of the snow in the hollows round the stems, caused by the heat of the sun absorbed by their dark surfaces. It gave me a long chase, flying rapidly, but never rising higher than three or four feet above the level of the snow. At last I got a long shot at it. It was alive when I secured it; and I remarked its brilliant, large, pale, blood-red eye. The legs were brown, and the bill nearly black. I shot a second example on the 1tth of June; it was busily engaged in searching for insects, principally at the roots of trees. This was all I saw of this bird. Both my birds are males, but not in the fine metallic blue plumage which old birds attain. I was probably at the extreme limit of this bird's northern range.

Calliope cantchatiensis (Gmel.).

I only met with this very handsome bird once within the Aretic circle. This was on the 14 th of June, whilst the ice was still straggling down the river. Early in the morning, before breakfast, Blue-throats were singing lustily. One bird 
struck me as having a wonderfully fine song, richer and more melodious than that of the Blue-throat, and scarcely inferior to that of a Nightingale. I shot him to be quite sure that he was only a Blue-throat, and was astonished to pick up a fine male Ruby-throated Warbler. I did not meet with this bird again until I reached Yen-e-saisk' on my return journey. It was then the 16th of August, and I was cxploring the reedy swamps near the river. Ny attention was attracted to a bird hidden annong the Curices, which was uttering a very loud harsh cry, like tic, tic, tic. After waiting some time I got a shot at it in a tall bunch of rushes. I felt quite sure that the bird was a large Acroceplucelus, and was astonished to find a second male Ruby-throat.

Saxicola enantue (Linn.).

The Wheatear arrived at our winter quarters on the 3rd of June, and was common as far north as we rent.

Pratincola indica, Blyth.

The Indian form of the Stoncehat, with pure white unspotted rump and ncarly black axillaries, was rarc. I noticed it first on the 11th of June on the Arctic circle, and afterwards in lat. $67^{\circ}$.

Sylvia curruca, Linn., subspecies affinis, Blyth.

I first noticed the Lesser Whitethroat on the 8th of June, and did not observe it further north than lat. $67^{\circ}$. In 'Stray Feathers,' iii. p. 372, Mr. Brooks endeavours to show that the Indian bird differ's from ours. Of the six differences which he there points ont I camnot detect any but the first. There is no doubt that in the eastern bird the wing is generally somewhat more rounded than in the western form; but whether this is sufficient to cutitle the two forms to specific rank I feel considerable doubt. In ten skins from England, Norway, Heligoland, Russia, Turkey, and Asia Minor, the second primary is decidedly longer than the sixth. In one skin from India and one from the Yen-e-say' this is also the case. In five slins from India and five skins from the Yen-e-say' the second primary is shorter than the sixth, but longer than the seventh; and in one skin from Cawnpore and one from Be- 
loochistan the second primary is shorter than the seventh, but longer than the eighth. More evidence must, I think, be collected before we admit S. affinis even to be a satisfactory subspecies.

\section{Phylloscopus borealis (Blasius).}

A fortuight after the arrival of Phylloscopus trochilus, $P$. tristis, and $P$. superciliosus I had given up $P$. borealis in despair, when suddenly it arrived in great numbers, and became the commonest of the four species. The song is almost exactly like the trill of the Redovle, but not quite so rapid, and a little mureme... .in)!s. Its call-note is generally a single monotonous a izit, but sometimes made into a (louble note by dwelling on the first part, $d-z$, zit. It is less restless than the other Willow-Tiablers, by no means shy, and is easy to shoot. When I left the Arctic circle it had probably not commeneed to breed; but on the 6th of July I had the good fortune to shoot a bird from its nest at Egaska, in lat. $67^{\circ}$. The egres are larger than those of our Willow- Warbler's, pure white, and profusely spotted all orer with very small and very pale pink spots. They were five in number. The nest was built on the ground in a wood thinly scattered with trees, and was placed in a recess on the side of a tussock or little mound of grass and other plants. It was semidomed, the outside being composed of moss, and the inside of fine dry grass. There was neither feather nor hair used in the construction. I did not see this bird further north than lat. $69^{\circ}$.

Phylloscopus trochilus (Limn.).

"Śylvia icterina, Vicill.", Eversm. (nce Ticill.), Acld. ad Pall. Zoogr. Rosso-As. fasc. iii. p. 14 (1842).

Phyllopneuste eversmani, Bp. Consp. Gien. Arium, p. 289 (1850).

It was with very great pleasure that I heard the familiar song of this European bird on the 4 th of Jume on the Aretic circle, in the valley of the Yen-e-say', so much further east than it has hitherto been recorded. I afterwards found it common extending as fir northwards as lat. $70^{\circ}$. As this bird has never been found in India, it would secm probable that 
the Yen-e-say' Willow-Warblers winter in Persia, whence Blanford records them.

In the St.-Petersburg Museum I had an opportunity of examining the type of Eversmann's Sylvia icterina, which was afterwards rechristened by Bonaparte Phyllopneuste eversmanni. I found it to be a typical specimen of Phylloscopus trochilus.

Phylloscopus tristis, Blyth.

The Sibcrian Chiffchaff arrived on the Aretic circle on the 4th of June, and was a common bird there until we left. Even before the snow was melted in the forests its cheerful chivit'-chivet' was constantly to be heard. When feeding it is a most restless birl, sceming always to be in a hurry, as if its object were to corer as much ground as possible. Later on in the season it was much less difficult to shoot. Although it arrives so early, it appears to be a late brecler. The first nest I found was on the 2nd of July in lat. 67\% . We were taking in ballast after our second narrow escape from shipwreck. I went on shore for a few hour's shooting. Alongside the ship, on a grassy part of the river-bank, there were three Ost'-yak chooms, with a herd of ahout fifty reindeer. Fifty yards abore this cneampment the shore was very muddy, and between the river and the forest was a long gently sloping bank sprinkled over with willows. In these trees wisps of dry grass were hanging, caught between the forks of the branches, aud left there after the high water had subsided. In one of these, about two feet from the ground, a Siberian Chiffchaff had built its nest, or rather it had appropriated one of them for its nest. There was scarcely any attempt at interlacing stalks. It was undoubtedly the most slovenly and the most loosely constructed nest I remember to liave seen. It was scarcely more than a hole, about two and a half inches in diameter, with one side a little higher than the other. The entrance was somewhat smaller than the greatest size inside, which was very globular and carefully lined with Capercalsie and Willow-Grouse feathers, plenty of which would naturally be found so near to an Ost'-yak choom. I shot 
the bird from the nest, which contained three eggs. My next nest of this bird was taken on the 14th of July, and contained four eggs. It was placed in the branches of an alder-bush, about four feet from the ground, and within twenty rards of the water's edge. It was rather more carefully constructed than the one I previously found, and composed of dry grass, semidomed, and lined with Willow-Grouse feathers. The third nest I took on the island of MIah'-la Brek'-off-sliy, about lat. $70 \frac{1}{2}^{\circ}$. This nest was similar in construction to the others, but was placed in the rank herbage within a few inches of the ground. The eggrs in this and a fourth nest which I took the same day (July $15 \mathrm{th}_{2}$ ), were somewhat incubated. The Siberian Chiffehaft lays a bold round cgg, large for the size of the bird, pure white, spotted with dark purple-red, almost black. Sometimes the spots are of considerable size. I have no hesitation in saying that the eggs which Harvie-Brown and I brought from the Petchora, which we supposed to be eggs of this bird, were only musually small varietics of those of the common Willow-Warbler.

I did not meet with the Siberian Chiffchaff further north than $70 \frac{1}{2}^{\circ}$; but on the return journey I continually met with it as far south as Yen-c-saisk'. On these occasions it was carefully tending its newly fledged young. Its plaintive monosyllabic call-note was then often heard; but it appeared to have dropped the chivit' chivet'.

Phylloscopus ruscatus, Blyth.

On my return journey I spent a few days in the middle of August at Yen-e-saisk', devoting some time to the exploration of the banks of the Yeu-e-say'. The country was almost flat, and for miles I wandered across an extent of meadowland which had recently been cut for hay. This meariowland is intersected with numerous half-dried-up rirer-beds rumning parallel to the Ien-e-say'. These river-beds are full of tall Carices and various water-plants, and are almost concealed by willow trecs. Occasionally the water is open. One of the commonest birds in these swamps was Phylloscopus fuscatus; what we saw rere mostly roung birds not fully fledged. 


\section{Phylloscopus superciliosus (Gmel.).}

On the 4th of June, while the ill-fated 'Thames' was in the agonies of its first shipwreck, I was delighted to have my attention called away by the note of this interesting bird, which I recognized at once as the same which I had heard in Gaetke's garden on IIeligoland the year before. It is very fairly represented by the word weest. The bird soon became very common, frequenting almost exclusively the pine-forests on the banks of the Koo-ray'-i-ka and the Yene-say'. It was not particularly shy; and on more than one occasion I watehed it for some time at a distance of only a few fect. On one occasion only I heard it make any attempt at a song; this was on the 21st of June. The bird was perehed upon the extreme summit of a spruce, and stood shivering its wings, uttering a few plaintive notes, most of them poor and feeble variations on its call-note. On the 26th of June I was fortunate enough to find its nest. Curiously enough I was this time also in company with a Hcligolander, Mr. Boiling, the ship-builder of Yen-e-saisk'. Late in the evening we were strolling through the forest between the Koo-ray'-i-ka and the Yen-e-say'. As we were walking along a little bird started up near us, and began most persistently to utter the well-known cry of the Yellow-browed Warbler. As it kept flying around us from tree to tree, we naturally came to the conclusion that it had a nest near. We searched for some time unsuccessfully, and then retired to a short distance, and sat down upon a tree-trunk to watch. The bird was very uneasy, but continually came back to a birch tree, from which it frequently made short flights towards the ground, as if it was anxious to return to its nest, but dare not whilst we were in sight. This went on for about half an hour, when we came to the conclusion that the nest must be at the foot of the birch tree, and commenced a second search. In less than five minutes I found the nest, with six eggs. It was built in a slight tuft of grass, moss, and bilberries, semidomed, exactly like the nests of our TiliowWarblers. It was composed of dry grass and moss, and lined with reindeer-hair. The eggs were very similar in colour to 
those of our Willow-Warl)ler, but more spotted than usual, and smaller in size. I did not meet with this bird further north than lat. $70^{\circ}$, nor did I see it on the return voyage.

\section{Achocemialus schenobenus (Limn.).}

It is rather remarkable that the Sedge-W Warbler should have hitherto been overlooked in Siberia. It arrived on the Arctic circle on the 15th of June, and soon became very abundant; but I did not obscrve it further north than lat. $67^{\circ}$.

\section{Acrocephalus dumetorum, Blyth.}

I did not meet with this bird until the 8th of August, on my return journey, in lat. $62^{\circ}$, where it was evidently breeding.

\section{Locustella certhola (Pall.).}

As I passed through Yen-e-saisk' on my return journey, towards the end of August, I found this rare GrasshopperWarbler breeding in the swampy thickets near the banks of the river. The young in first plumage from this locality will be described and figured in Dresser's 'Birds of Europe.'

I found it very shy and skulking in its habits. The young. birds, some only half fledged, were still in broods; and oceasionally I got a shot at one which left the sedges and rentured into the willows. 'They were calling anxionsly to each other', the note being a harsh tic, tic, tic.

Autlientic slins of this bird in first plumage, now for the first time olstained, are very interesting. They prove that the various skins to be found in collcetions labelled $L$. ochotensis by Dybofisky, from Lake Baical, are simply the young of $L$. certhiota. The general colour of the underparts of the young in first plumage is buffish yellow, darkest on the breast and flanks, and inclining to chestnut on the under tail-coverts. In first winter plumage this yellow tinge is retained; but it is lost in the spring moult, the general colour of the underparts being then buffish white, darkest on the breast, flanks, and under tail-coverts. A third state of plumage is that of the adult after the autumm moult, in which the buff of the underparts almost approaches chestnut. In this state (gradually becoming duller by abrasion as the winter wears on) it is the $\left[5^{6}\right]$ 
L. rubescens of Blyth. Jerdon seems to have been acquainted with all three states of plumage. The young and adult in summer plumage he describes under the name of $L$. certhiola (Pall.); but doubtful of the identity of the Siberian and Indian birds, he proposes the name of $L$. temporalis for the latter, in case they should afterwards be found to be distinct. The autumn plumage of the adult he describes as $L$. rubescens, Blyth, but alludes to that ornithologist's opinion that it might be identical with Pallas's bird. Salvadori's Calamodyta doriæe is $L$. certhiola in winter plumage from Borneo. When I was in Paris l'abbé David told me that the type of Locustella minor, David et Oustalet, was lost; but he assured me, what I was already prepared to assert, that it is a bad species, and the name must sink into a synonym of $L$. certhiola. Full references to all these synonyms will appear in Dresser's 'Birds of Europe.'

Locustella ochotensis, Midd.

Sylvia (Locustella) ochotensis, Midd. Sib. Reis. ii. p. 185 (1851). Young in first plumage.

Sylvia (Locustella) certhiola, Midd. Sib. Reis. ii. p. 184 (1851, nec Pall.). Adult.

Jocustella japonica, Cassin, Proc. Ac. Sc. Phil. 1858, p. 194. Young.

Locustella subcerthiola, Swinhoe, Ibis, 1874, p. 154. Adult. Arundinax blakistoni, Swinhoe, Ibis, 1876, p. 332. Young in first winter plumage.

The synonymy of $L$. ochotensis and $L$. certhiola have hitherto been in such hopeless confusion that I am glad to have an opportunity of putting them in something like order. When I was in St. Petersburg the curator of the Museum, with the politeness so characteristic of the Russians, gave me every facility for inspecting types and other interesting skins in the collection. I found that all the skins collected by Middendorff near the shores of the Sea of Ochotsk, labelled respectively $L$. certhiola and $L$. ochotensis, belonged to one species, the former being adult birds, and the latier young in first plumage. The difference between them lay solely in the 
general colour of the underparts. This was buffish white in the adult birds, and buffish yellow in the young, precisely the difference which I had found only a few weeks before between the adult and young of the very closely allied $L$. certhiola. None of Middendorff's birds, however, were the true L. certhiola of Pallas. The name L. ochotensis, Midd., therefore stands for this species, with L. certhiola, Pall. apud Midd., as a synonym. Besides Middendorff's type I found a fine series of skins of this bird collected by Wosnessensky in Kamtchatka and the Kurile Islands. This bird differs from $L$. certhiola in having the upper parts plain, like $L$. luscinioides, instead of spotted, like. L. næevia. Young birds have, however, traces of obscure spots on the head and back. In this state it was described by Cassin as L.japonica from Japan. The young in first winter plumage was described by Swinhoe as Arundinax blakistoni, from the same locality. One of Wosnessensky's skins from Kamtchatka came into Swinhoe's possession, and was described by him as $L$. subcerthiola. It is that of an adult bird, and agrees exactly with a skin in my collection collected by Wosnessensky on Urup island, one of the Kurile Islands, between Kamtchatka and Japan. In the British Museum is a skin from Labuan, in Borneo, where this species winters.

Locustella fasciolata (Gray).

Acrocephalus fasciolatus, Gray, P. Z. S. 1860, p. 349.

Acrocephalus insularis, Wallace, Ibis, 1862, p. 350.

Calamoherpe fumigata, Swinhoe, P. Z. S. 1863, pp. $91,293$.

Calamoherpe subflavescens, Elliot, P. Z. S. 1870, p. 243.

It may at first sight appear a somewhat bold step to take to unite two species hitherto considered so distinct as $A$. fasciolatus and $A$. insularis, and a still bolder one, after having married the two species, to send them to spend their honeymoon in the genus Locustella. The fact is that they agree in every particular, except in the colour of the underparts. The difference of colour, however, is exactly what we have just found to be the difference between young and adult plumage in two species of the genus Locustella. I have already [58] 
given my reasons in the last number of 'The Ibis' for placing this species in that genus. In the Museum at St. Petersburg are two very beautiful skins of adult birds of this species from the Ussuri river. Young birds have been obtained by Dyboffsky in Daouria, and have been described by Elliot as $C$. subflavescens from the same locality. Swinhoe described the adult passing through China on migration, as C. fumigata, and also recorded it from Japan. Wallace described $A$. insularis from Gilolo and Morty; and Gray described his $A$. fasciolatus from skins collected by Wallace in Batchian, Gilolo, and Morty. I think I may fairly claim that all the known facts of the geographical distribution of these two birds are in favour of my theory that they are young and adult of one species.

Accentor montaneluus (Pall.).

I first noticed this bird on the 19th of June, a quiet skulking bird, rarely seen on the wing, and principally frequenting the willows near the banks of the Yen-e-say'. Four days afterwards I had a long chase on the Koo-ray'-i-ka side of the river after a bird whose song I had frequently heard before. It was a short unpretentious song, something like that of our Hedge-Sparrow. The bird was generally on the top of a high tree, where it sang its short song, and went onto another tree. At last I succeeded in shooting it from the top of a pine, and was astonished to find it the Mountain-Accentor. I did not meet with it again until I reached lat. $70 \frac{10}{2}$, where I found it breeding in the island of Mah'-la Brek'-off-sky. Here it was skulking among the willows, like a Grasshopper-Warbler. The nest was within a foot of the ground; but I was so worried with mosquitoes that I neglected to note the materials of which it was composed. The eggs are blue, like those of our Hedge-Sparrow. I did not meet with it further north.

Hirundo. Rustica, Linn.

On the 16th of May a solitary Barn-Swallow appeared. I did not see another until we were within a hundred miles of Yen-e-saisk' on the return journey. At that town they were common enough. 
Chelidon lagopoda (Pall.).

In the 'Proceedings' of the Zoological Society, 1862, p. 320, Swinhoe described a Martin which differs from ours in having the upper tail-coverts white to the tips of the feathers, and the axillaries and wing-lining dark brown. He gave it the name of $C$. whitelyi; but in 'The Ibis,' 1874, p. 152, he pointed out that it is identical with the Hirundo lagopoda of Pallas. This bird was the only Chelidon which I obtained on the Yene-say'. Several pairs arrived on the Arctic circle on the 1lth of June, and were soon busy hawking for flies and examining their old nests. In the village of Koo-ray'-i-ka, opposite the mouth of the river of that name, they swarmed in thousands. The nest exactly resembles that of our House-Martin; but the birds seemed to be very capricious in selecting a house where they might trust their young. One house in particular seemed to be the favourite; and here the eaves were crowded with rows of nests, in some places three or four deep. The eggs are, if any thing, larger than those of our bird, but also pure white. I observed this bird up to lat. $69^{\circ}$, where a few pairs were breeding. I could not perceive any difference in the habits or notes of these birds and those of our own species. On the return journey I noticed a colony, doubtless of these birds, which had built their nests against the limestone cliffs of the $\mathrm{Kah}^{\prime}$-nin Pass, as our bird frequently does in the limestone districts of Yorkshire, the Parnassus, \&c. As I passed through Yen-e-saisk' in the middle of August, the House-Martins were swarming on the church-towers, preparing for departure on their autumn migration.

When these Swallows began to make preparations for breeding, the 'Thames' was riding at anchor in the Koo-ray'-i-ka. Some scores of these birds evidently took a great fancy to the ship, and began to build their nests on the sails under the yardarms.

Cotyle riparia, Linn.

The Sand-Martin arrived on the Arctic circle on the 9th of June. Both on the banks of the $\mathrm{Ob}$ and the Yen-e-say' large colonies of these birds were frequent. I did not see 
any further north than lat. $67^{\circ}$. Siberian birds, like those of North Europe, are somewhat darker brown above and purer white below than our Sand-Martin. 
Tétrao urogallus, Linn.

The Capercailzie was not nearly so common as the Black Grouse; but I succeeded in obtaining two males and two females. I shot the first female on the 29th of April. In this bird the feathers on the feet extended halfway down the last joint of the toes, within a quarter of an inch of the claws. The second example was shot on the 10th of June; and the feathers on the feet extended only halfway down the first joint of the toes, nearly an inch and a half from the claws. The crops of these birds were full of the spine-like leaves of the cedar and Scotch fir. I saw no trace of T. urogalloides.

Tetrao tetrix, Linn.

Black Grouse were common during our stay at Koo-ray'i-ka. They appeared to find abundance of food in the buds of the birch and hazel in the severest weather. It was not an uncommon thing to see half a dozen of them in one tree together. We saw no more of them after passing the limit of forest-growth.

Tetrastes bonasia (Linn.).

I shot the first pair of Hazel-Grouse on the 3rd of May, and occasionally picked up a pair afterwards. On the 25th of June I took a nest with eight eggs. These birds were very easy to shoot. When disturbed from the ground they took refuge in a tree, where they allowed themselves to be easily stalked, not appearing to be alarmed at the rattling of my snow-shoes on the hard crust of the snow. The sailors told me they had been common in the autumn, but had disappeared 
in the severest part of the winter. Their crops were full of the buds of birch and hazel.

Lagopus albus (Gm.).

The Willow-Grouse is a migratory bird in Siberia. It breeds on the tundra, and winters in the forests. As we sledged down the Yen-e-say' in April we once or twice saw flocks of these birds flying northwards, apparently on migration. The sailors told me that Willow-Grouse were common at the Koo-ray'-i-ka in autumn, but disappeared in midwinter. The first I shot was on the 15 th of May. It was in full winter plumage, except a band of chestnut feathers round the neck; but on raising the white feathers on the crown the new crop of chestnut feathers was visible.

I very seldom saw a bird until the ice on the river began to break up, when they were more plentiful for a week or two, after which they disappeared from the forests. A bird I shot on the 6 th of June was in full winter plumage, except a chestnut ring round the neck, a sprinkling of chestnut feathers on the crown, and two or three chestnut feathers on the shoulders and scapulars. On the 4 th of July, in lat. $67^{\circ}$, where patches of tundra were found between the forest and the river, I found them breeding in full summer plumage. On the 22nd of July, in lat. $71 \frac{1}{2}^{\circ}$, they had young.

Lagopus rupestris, Gm.

Professor Newton was the first to point out to me the fact that my Yen-e-say' skins labelled $L$. mutus were not that bird, but most probably $L$. rupestris. I brought home two males and a female, all shot on the 22nd of July, in lat. $71 \frac{1}{2}^{\circ}$, four or five hundred feet above the level of the sea. I also brought home a skin in winter plumage in which the space between the eye and the bill is black; but as I bought it in a frozen state on the Arctic circle, it may have been brought down from a locality much further north.

The female differs from a female of $L$. albus, shot on the same day in the valley, in having a slenderer bill, and in having the feathers of the back mostly tipped with white, and rarely with ochraceous, whereas in the Willow-Grouse they 
are mostly tipped with ochraceous, rarely with white. The males differ from the female in having the ochraceous bars narrower, more numerous, and interrupted, making the general effect of the plumage of the upper parts darker and richer. The throat and breast are rather paler than the back. The belly and under tail-coverts of one are white, and in the other the feathers on the flanks are half white and half mottled black and ochraceous, on the under tail-coverts all mottled, and on the belly half white and half mottled ash-grev and ochraceous.

So far as I know, this is the first record of this species on the mainland of the Palæaretic region. In size my skins of this bird are smaller than those of the Willow-Grouse, measuring in length of wing $7 \frac{1}{2}$ to $7 \frac{3}{4}$ inches against $7 \frac{3}{4}$ to 8 inches (measured with a tape across the upper surface of the wing).

Botaurus stellaris (Linn.).

I brought home the skin of a Bittern which I found hanging up in a peasant's house in a little village on the banks of the Yen-e-say', in lat. $61^{\circ}$. The peasant told me that he had shot it in the neighbourhood some time during the previous summer.

Grus communis, Bechist.

I first observed the Crane about lat. $60^{\circ}$ on my retur'n journey up the Yen-e-say' on the 12th of August, when small parties were migrating southwards. I frequently saw these birds at Yen-e-saisk' during the few days I remained at that town; and afterwards they were not uncommon on the $\mathrm{Ob}$ and the Too'-ra.

Grus leucogeranus, Pall.

A small flock of four or five of these handsome birds flew leisurely over our steamer as we were threading the labyrinths of the Too'-ra. During flight they appeared to be pure white all over, except the outside half of each wing, which looked jet-iblack.

Tringa temmincki, Leisl.

As soon as the snow had melted on the banks of the river, 
so that patches of bare grass were visible in favourable places, these oases were visited by small parties of Temminck's Stints. I shot the first on the 6th of June. Most of these birds migrated further north; but a few remained to breed, and on the 2 th I found a nest containing two eggs on the south bank of the Koo-ray'-i-ka.

Further north, wherever we landed on the shores of the river or on the islands of the delta, Temminck's Stint was by far the commonest Sandpiper. I brought home several sittings of its egg's, both from the Brek'-off-sky islands in lat. $70 \frac{1}{2}^{\circ}$, and from Gol-check' $-a$, in lat. $71_{2}^{\frac{1}{2}}$. On my return journey I found it plentiful on the banks of the Yen-c-say' in in lat. $58^{\circ}$ in the middle of August. These birds had probably not bred so far south, but were most likely slowly migrating southwards towards thcir winter quarters.

Tringa minuta, Leisl.

I did not see any trace of the Little Stint until I reached Gol-cheek'-a, in lat. $71 \frac{1}{2}^{\circ}$, on the 19th of July. It was then too late for eggs. I had, however, been fortunate enough to charter a Samoyade, who brought me a couple of baskets full of unblown eggs. In this collection were nine eggs so cxactly like those of the Little Stint which Harvie Brown and I obtained near the banks of the lagoon of the Petchora, that I only required to see the birds in the neighbourhood to feel sure of their identity. I spent the following day on the tundra, and secured two female Little Stints; and on the 22nd I secured a male of this species.

Tringa subarquata, Güld.

On the 15th of June I obtained a fine Curlew Sandpiper in full breeding-plumage at the village of Koo-ray'-i-ka, on the Arctic circle. It was doubtless en route for its breedinggrounds, nearer the sca than I was able to get, as I saw nothing more of this interesting species.

The eggs of this bird and those of the Knot are now the two great prizes left for British oologists to try and secure. Drs. Finsch and Brehm found the Curlew Sandpiper breedingin great numbers about the 1st of August on the isthmus of 
the Yalmal peninsula, near the margins of the lakes on the tundra, about lat. $67 \frac{1}{2}^{\circ}$. They were too late for eggs, but had young in down in their hands. The mosquitoes, however, were so overwhelming that these adventurous ornithologists failed to bring home any specimens of this still unknown state of plumage. Capt. Feilden was more fortunate with the Knot. He brought home young in down obtained during the late Arctic Expedition. This bird was breeding in lat. $82 \frac{1}{2}^{\circ}$, on the shores of the Polar basin, a little to the north of Cape Union; and the young in down were obtained on the 30th of July. It was also breeding on both shores of the channel at Thank-God Harbour and Discovery Bay, in lat. $81 \frac{3}{4}^{\circ}$.

\section{Tringa alpina, Linn.}

I saw nothing of the Dunlin until the 14th of July, when I shot a couple of males in lat. $69^{\circ}$; and four days later I shot a male and female in lat. $71 \frac{1}{2}^{\circ}$. With these birds were young in down. I am indebted to my friend Mr. Charles Murray Adamson, of Newcastle, who has paid great attention for many years to the changes in the plumage of the Waders, for pointing out to me the interesting fact that these birds are all moulting nearly the whole of their primaries at once, to such an extent as to incapacitate them for extended flight, and at a much earlier period than is the case in this country. $\mathrm{Mr}$. Adamson suggests that in the high latitudes, where the summer is so short, the parent birds probably migrate with their young, instead of a fortnight later, as is usually observed in this country, Heligoland, \&c." 'To enable them to do so the autumn moult must take place at an earlier date.

Machetes pugnax (Linn.).

The Ruff was a common bird in the valley of the Yen-e-say'. I shot the first on migration on the 9 th of June on the Arctic circle; and afterwards I met with them wherever there was long grass in the swamps of the tundra as far north as I travelled.

Actitis hypoleuca (Linn.).

I shot the first Common Sandpiper on the 12th of June, [66] 
and found it frequent on the banks of the river wherever I went.

T'erekia cinerea (Güld.).

The Terek Sandpiper arrived at our quarters on the 8th of June, and was common on the banks of the river and islands as far north as lat. $70^{\circ}$.

\section{Limosa lapponica (Linn.).}

The only trace of the Bar-tailed Godwit which came under my notice was a single bird which Schwanenberg's mate shot for me on the Brek'-koff-sky islands during the spring migration.

Totanus glareola (Linn.).

Next to Temminck's Stint the Wood-Sandpiper was by far the commonest Wader in the valley of the Yen-e-say'. I shot the first on the 6th of June at the Koo-ray'-i-ka, but did not meet with it north of lat. $69^{\circ}$.

Totanus ochropus (Linn.).

I shot my first Green Sandpiper on the 15th of June, on the Arctic circle. It was by no means a common bird. On the 6th of July, at Egarka, in lat. $67^{\circ}$, I found a nest of this bird in a willow tree, about six feet from the ground, containing one egg. I did not meet with it further north ; but on my return journey, early in Augnst, I found it common on the banks of the river near Yen-e-saisk'.

Vanellus vulgaris, Bechst.

I did not meet with the Lapwing until we had nearly reached Tyu-mane' on the return journey.

Charadrius pluvialis, Linn.

I shot the first Golden Plover on the banks of the Kooray'-i-ka on the 7th of June, and found it common on the tundra as far north as we went. On the return journey I spent some hours near Vare'-shin-sky, in lat. $69^{\circ}$, on the 29th of July, and saw several pairs of Golden Plovers. They were very anxious to lead me away from their young. Occasionally they uttered their plaintive cry from the ground, but 
more often from the summit of a larch tree. I shot one from the top of a larch at least fourteen feet from the ground.

\section{Charadrius fulvus, Gmel.}

On the 5th of June I had the pleasure of shooting my first Asiatic Golden Plover. This bird is at once distinguishable from the last-mentioned species by its smaller size, and grey instead of white axillaries. A third distinction may also be found in the comparatively longer tarsus of the eastern bird. In its voice it exactly resembles the Grey Plover. I noticed all the three variations with which I am so familiar in the note of the latter bird, but remarked that the third variation, which I take to be a combination of the two others more rapidly uttered (see Dresser's 'Birds of Europe,' Appendix to the article on Squatarola helvetica), is much more frequently uttered by the Asiatic Golden Plover than by the Grey Plover. I secured many specimens of this interesting bird as it passed the Koo-ray'-i-ka on migration. I did not observe it again until we reached lat. $69 \frac{10}{2}$, on the open tundra just beyond the limit of forest-growth. Not a trace of a pine tree was to be seen; and the birches had dwindled down to stunted bushes scarcely a foot high. I took a nest of Turdus fuscatus with young birds as I climbed up the steep bank where alders and willows still flourished luxuriantly, and had scarcely reached the top before I heard the cry of a Plover. The tundra was hilly, with lakes and swamps and bogs in the wide valleys and plains. I found mysclf upon an excellent piece of Plover-ground, coverted more with moss and lichen than with grass, sprinkled with patches of bare pebbly ground, and interspersed with hummocky plains, where ground-fruits and gay flowers were growing. I soon caught sight of both male and female, and sat down with the intention of watching the latter onto the nest. After wasting half an hour, during which the bird wandered uneasily round and round me without showing any partiality for a special locality, I came to the conclusion, either that the eggs were hatched, in which case my watching was in vain, or that I was so near the nest that the female dare not come on. The male had a splendid [68] 
black belly; and I decided to take my first good chance of a shot at him, and then to devote another half hour to a search for the nest. He proved to be, as I suspected, the Asiatic Golden Plover, with grey axillaries. My search for the nest was a very short one. I found it in less than five minutes, within a dozen yards of my position. It was a mere hollow in the ground upon a piece of turfy land, overgrown with moss and lichen; and it was lined with broken stalks of reindeer moss. 'The eggs, four in number, were a size smaller than those of the Golden Plover, averaging $1 \frac{3}{4} 6 \times 1 \frac{13}{40}$. (Eggs of the Golden Plover from the same locality arerage $2 \frac{2}{40} \times$ $1 \frac{16}{40}$.) These eggs were talien? on the 13th of July, and were very much incubated.

Among the eggs which had been collected for me at Golchecka was a second sitting of Asiatic Golden Plover's. Here the bird was extraordinarily common. I tricd to watch several birds onto the nest, but in every case without success. They behaved exactly as if they had young. I succeeded in catching one young bird in down, and reluctantly came to the conclusion that I was too late (on the 20th of July) for eggs. The young in down is quite as yellow as that of the Golden Plover.

In 'The Ibis' for 1863, p. 404, Swinhoe represents this bird as breeding plentifully on- Formos?. The eggs are described as measuring $1 \frac{20}{40} \times 1_{40}^{4}$. Tincse cgggs are still in the Swinhoe collection, and average $1_{40}^{17} \times 1_{ \pm 0}^{2}$. They exactly rescmble my eggs in colour, but are much smaller and rounder at the small end. Two other eggs in the same collection, of exactly the same colour and shape, and from the same locality, are marked AEgialitis geoffroii. These two eggs are a shade smaller, measuring $1 \frac{1}{40} \times 1$; but $I$ am induced to think that Swinhoe has been led astray by his collectors, and that all these Formosa eggs belong to $\mathscr{E}$. geoffroii. Swinhoe further states that $C$. fulvus is common on Formosa "all the year round." Unfortunately the skins of this bird from Formosa in the Swinhoe collection are not clated. I have no doubt that great numbers of this bird pass through Formosa in breeding-plumage in spring, and again in winter plumage in autumn. Some may very 
probably winter in so southern a station as Formosa; and after what Capt. Legge tells me of similar occurrences in Ceylon, I can imagine that barren birds in imperfect breedingplumage may not unfrequently be found during summer in their winter quarters; but I scarcely think it possible that $C$. fulvus breeds south of the Arctic circle, at least three thousand miles further north than Formosa. If any of these Formosan eggs are those of $A$. geoffroii, it is evidence, as far as it goes, that this bird is a Eudromias, and not an Egialitis; for they are almost miniatures of the eggs of the Dotterel, E. morinellus.

Eudromias morineluus (Linn.).

Small parties of Dotterel appeared from the 9th of June for about a week at the Koo-ray'-i-ka. I did not meet with this species again until the 25th of July, on my return journey, when, in lat. $71^{\circ}$, I shot a male and picked up a young bird in half down and half feathers.

Egialitis hiaticula (Linn.).

The Ringed Plover arrived on the 8th of June at our winter quarters, and was common as far north as I went (lat. $71 \frac{1}{2}^{\circ}$ ).

\section{Phalaropus hyperboreus (Linn.).}

The Red-necked Phalarope arrived at the Koo-ray'-i-ka on the 15 th of June, and was abundant as far north as I went.

\section{Gallinago stenura (Kuhl).}

The first Wader which arrived at our winter quarters on the Arctic circle was the Pin-tailed Snipe. We shot a couple on the fifth of June, three days after the ice began to break up on the great river. Three days later they were exceedingly common on the oases of bare grass which the sun had been able to make in a few favourable situations in the midst of the otherwise universal desert of melting snow. I could easily have shot a score a day if I had had cartridges to spare. They used to come wheeling round, uttering a loud and rather shrill cry (some idea of which may be gathered by the sound of the word peezh, long drawn out); then they used to drop down with a great whiry of wings, and with tail outspread$[70]$ 
an operation which seemed so engrossing that they appeared seldom to discover until they were on the ground that they had chosen a spot to alight within twenty yards of a man with a gun. It was amusing to see them find out their mistake. Sometimes as soon as they caught my eye they would take wing and fly quietly away; but more often they would hurry off as fast as their legs would carry them, and hide behind a tuft of grass or a bush. I never heard the Pin-tailed Snipe "drum," as the Common Snipe often does, when wheeling round and round at a considerable height in the air ; nor did I ever hear the tyik-tyuk so characteristic of the Common Snipe. I think the Pin-tailed Snipe is much easier to shoot than our bird. The flight seems to me slower and less zigzag.

Gallinago scolopacina, Bonap.

The Common Snipe was either much rarer or much more wary than the Pin-tailed Snipe; for out of twenty skins which I brought home with me four proved to be those of G. scolopacina, and sixteen those of $G$. stenura. They probably arrive on the Arctic circle at the same time, as my first Pintailed Snipe was shot on the 5th of June and my first Common Snipe on the 9th. I found a nest of the Common Snipe in a marsh on the outskirts of the forest in lat. $67^{\circ}$ on the 6 th of July. The eggs were considerably incubated. I can find no differences in size or general coloration in these two Snipes; but a minute examination discloses the following characters :-My skins of $G$. scolopacina vary in length of culmen from 2.87 to 3 inches, whilst those of $G$. stenura only measure from $2 \cdot 33$ to $2 \cdot 73$. G. stenura may be always at once recognized by the very narrow and stiff feathers on each side of the tail. The tail of this bird is also shorter, in my skins varying from $1 \cdot 65$ to $1 \cdot 9$. In my skins of $G$. scolopacina the length of the tail varies from $2 \cdot 4$ to $2 \cdot 6$. In G. stenura the under wing-coverts are all distinctly barred with black, whilst in G. scolopacina many of them are pure white. These two species of Snipe probably breed north of the Arctic circle, as I saw nothing more of them at the Koo-ray'-i-ka after the middle of June. 


\section{Gallinago major (Gmelin).}

Six days after the arrival of the Pin-tailed Snipe the Double Snipetappeared in considerable numbers, and soon became by far the commonest species. In the ercnings I used sometimes to watch these birds through my binocular. With a little caution I found it easy to get very near them ; and frequently I have sat partially concealed between a couple of willow bushes attentively turning my glass on two or three pairs of these birds, all within fifteen or twenty yards of me. They used to stretch out their necks, throw back the head almost onto the back, and open and shut their beaks rapidly, uttering a curious noise, like running one's finger along the edge of a comb. This was sometimes accompanied by a short flight or by the spreading of the wings and tail. The Double Snipe is by no means shy, and allows of a near approach. When it gets up from the gromind it rises with a whirr of the wings like that of a Grouse, but not so loud. The Double Snipe probably breeds on the $\Lambda$ retic circle, as it still frequented the marshy ground near the Koo-ray'-i-ka when we weighed anchor in the ill-starred 'Thames' on the 29th of Junc, and I found it still frequenting the same locality when I returned in the 'Yen-e-say' on the 2nd of August.

\section{Crgnus musicus, Bechst.}

I did not suceed in identifying the common Wild Swan in the valley of the Yen-e-say'. Every skin which I had an opportunity of examining proved to be that of Bewick's Sran ; cvery footprint in the sand which I measured was that of Bewick's Swan; and all the eggs I obtained agreed in size with those of Bewick's Swan which Harvie Brown and I obtained in the Petchora, and were too small for those of the larger species. Nevertheless there cannot be any doubt that Cygnus musicus is found in the valley of the Ien-e-say', since Middendorff found it still further to the east, and it is common on the Amur. I examined a number of skins at various stations between Tomsk and Tobolsk, and found both species represented in nearly equal numbers. 


\section{Crgnus minor, Pall.}

We saw the first Swan on the Koo-ray'-i-ka on the 5th of May; but it was not before the 31 st of that month that Swans passed over in any number. After the latter date thousands passed us, all flying north. I brought several eggs of Bewick's Swan home with me, obtained in lat. $69 \frac{1}{2}^{\circ}$. I found the easiest way of identifying these birds was by measuring their footprints in the sand. From the centre of the ball of the heel to the centre of the ball next the claw of the middle toe, the impression of the foot of Bewick's Swan measures $5 \frac{1}{4}$ inches, whilst that of the common Wild Swan measures upwards of 6 inches. Even in very slight impressions on hard wet sand I found it easy to make these measurements.

\section{Anser segetum, Gmel.}

The first Goose was seen at our winter quarters on the 9th of May. Whenever the weather was mild during May small parties of Geese flew over the ship in a northerly direction. When the wind changed and brought us a couple of days' frost or snow, we used to see the poor Geese migrating southwards again. The great annual battle of the Yen-e-say' lasted longer than usual the year that I was there. We had alternate thaws and frosts during the last three weeks of May. Summer seemed to be always upon the point of vanquishing winter, but only to be driven back again with redoubled vigour. During all this time there must have been thousands and tens of thousands of Geese hovering on the skirts of winter, continually impelled northwards by their instincts, penetrating wherever a little open water or an oasis of grass was visible in the boundless desert of ice and snow, and continually driven southwards again by hard frosts or fresh falls of snow. It was not until the ice on the great river broke up that the great body of Geese finally passed northwards. On my return journey I had an opportunity of again witnessing a great stampede of Geese on the tundra in full moult and unable to fly. The first time I witnessed this interesting sight was near the delta of the Petchora two years previously. Then it was 
on the 27 th of July, and in the valley of the Yen-e-say' on the 25 th of that month.

\section{Anser erythropus, Linn.}

On the 1st of June a small flock of Geese passed close over my head as I was lying hors de combat in a snow bank, the treacherous crust of which had given way and left me struggling up to my breast endeavouring to extricate myself without wetting my gun. These Gecse were smaller than the Bean-Goose, and showed some black on the belly. I afterwards shot some of the same species and brought two skins home, which proved to be the Little White-fronted Goose.

\section{Bernicla ruficollis (Pall.).}

On the lst of July the two mates belonging to Capt. Schwanenberg's schooner were out on the next island to that where their unfortunate ressel was lying wrecked. I had chartered them to collect eggs for me on the Brek'-off-sky islands in the Yen-e-say', in lat. $70 \frac{1}{2}^{\circ}$. They were fortunate enough on that day to come suddenly upon a Red-necked Goose upon her nest. They shot her before she flew off, and, unfortunately, broke one of the two eggs upon which she was sitting. 'The other egg is now in my collection. It measures $2 \frac{28}{4}$ by $1 \frac{34}{4}$, and is of a dirty-white colour, more or less inclining to cream-colour.

On the 28th of July, as we were slowly steaming up the river, against stream and close inshore, I saw several of these very handsome birds with their young broods on the banks of the river. The captain was very anxious to get to Dudinka before Sot-ni-koff's stcamer arrived there; so there was no possibility of going on shore. This was a few miles south of the island where my egg was taken.

Anas clypeata, Linn.

I shot a fine male Shoveller on the tundra near the village of Koo-ray'-i-ka on the 18th of June. This was a piece of moorland surrounded with forest, where many species of Duck were breeding. I very seldom saw this species in the valley of the Yen-e-say'. 
Anas crecca, Linn.

As soon as the ice broke up on the river, Teal became very numerous; and on the 20th of June I took a nest with two eggs. I took the last Teal's nest on the 15th of July, in lat. $70 \frac{10}{2}$, with fresh eggs.

Anas acuta, Linn.

The Pintail was one of the commonest Ducks on the Yene-say'. I took a nest with six eggs on the 20th of June.

Anas Penelope, Linn.

The Widgeon was very common at our winter quarters as soon as the ice began to break up; and its weird cry, mēé $-y$ ŏo, harmonized with the grating of the pack-ice and the splashing of the "calving" icebergs. I took the first nest, with seven eggs, on the 18th of June.

Anas boschas, Linn.

The only example of the Wild Duck which I procured was a female which I shot near Yen-e-saisk' on my return journey.

Fuligula Marila (Linn.).

I did not succeed in shooting a Scaup, but frequently recognized their harsh screams.

Fuligula clangula (Linn.).

The Golden-eye was not uncommon at the Koo-ray'-i-ka. I had a nest with thirteen eggs brought me on the 17 th of June.

Harelda glacialis (Linn.).

The Long-tailed Duck was common on the lakes on the tundra.

CEdemia nigra (Linn.).

Black Scoters were abundant at the Koo-ray'-i-ka, but so wary that I was never able to get within shot of them.

Mergus albellus (Limn.).

I never actually shot a Smew on the Yen-e-say', but had several opportunities of identifying the bird beyond doubt.

Mergus merganser (Linn.).

The Goosander was not uncommon at the Koo-ray'-i-ka; and I brought home several skins of this handsome Duck. 
Mergus serrator (Linn.).

The Red-breasted Merganser was common near the village of Koo-ray'-i-ka. I brought home skins of males in two plumages and one of a female.

Somateria spectabilis (Linn.).

Kitmanoff, the captain and part owner of the steamer 'Yen-e-say',' in which I returned from Gol-cheek'-a to Yene-saisk, had a King Eider stuffed in his cabin. He told me it was shot at Gol-cheek'-a. Capt. Wiggins told me this bird breeds in great numbers together with the common Eider on a large island in the By-der-at'-sker-y bay. Both these birds are probably exclusively maritime in their habits, and are only accidentally seen so far from the coast.

Colymbus adamsi, Gray.

Besides the Black-throated and Red-throated Divers, I was frequently told of a still larger species of $G a-g a r^{\prime}-a$ with a white bill which frequented the lakes on the tundra.

Colymbus arcticus, Linn.

The Black-throated Diver was very common on the Yene-say' from the Koo-ray'-i-ka to Gol-cheek'-a.

Colymbus septentrionalis, Linn.

The Red-throated Diver was not quite so common as the preceding species. The crics of these birds, exactly like the screams of a child in great pain, were constantly heard during the grand crash of ice in which our first shipwreck occurred.

Sterna macrura, Naum.

On the 6th of June I saw the first Arctic Tern, and found it abundant in various localities further north.

Larus canus, Linn:

The Common Gull arrived at the Koo-ray'-i-ka on the 1st of June, and remained to breed. I got fresh eggs on the 17th of June. As in the Petchora, so also in the Yen-e-say' valley, I noticed its somewhat singular habit of perching in trees. I did not observe this species of Gull on the tundra.

Lirus glaucus, Fabr.

I did not succeed in shooting a bird of this species; but on [76] 
several occasions I saw large Gulls without the black tips to the wing-feathers, which were doubtless $L$. glaucus.

LARUS AFFinis, Reinhardt.

This yellow-legged Herring-Gull, with a mantle nearly as dark as that of L. fuscus, was first scen on the 31st of May. During the breaking up of the ice the wild cries of these birds were an appropriate accompaniment to the grand crash which shipwrecked us in the Koo-ray'-i-ka. As the ice broke up further north these Gulls left us; and we saw them no more until we reached lat. $69^{\circ}$. Here a large colony frequented an island in the river where several parties of Russians and Ost' yaks were fishing. This colony was almost entirely composed of birds in immature plumage; and there was nothing to lead us to suppose that any of them were breeding. Between lat. $70 \frac{1}{2}^{\circ}$ and $71 \frac{1}{2}^{\circ}$ we passed several breeding-stations of these birds, where it was a very rare thing to see a Gull in immature plumage. I should have been too late to secure fresh eggs of this species; but, fortunately, I had chartered a Russian at Brek'-off-sky and a Samoyede at Gol-cheek'-a to collect for me, and at each station I found a large basket of unblown eggs. As might have been expected, they vary somewhat in size and colour, and are not distinguishable from eggs of $L$. fuscus or $L$. argentatus. So far as it is possible to compare the cries of birds from memory, I may confidently affirm that these do not vary from those of $L$. argentatus or $L$. cachinnans.

When I was in St. Petersburg Russow was kind enough to unpack for me the whole of the splended series of Gulls in the Museum, which gave me an opportunity of obtaining some valuable information as to the geographical distribution of these closely allied species. Larus affinis appears to breed in the extreme north of Europe and Asia from the White Sea to Kamchatka. It has been obtained in the breeding-season on Bear Island, south of Solovetsk, in the White Sea (Midd., in Mus Petr.), on the Petchora (Seebohm \& Harvie Brown), on the Ob (Finsch \& Brehm), on the Yen-c-say', on the Boganida and Taimyr, near the North-east Cape (Midd., in Mus. Petr.), 
and in Kamchatka (Kittlitz, in Mus. Petr. fide Schrenk). In spring and autumn on migration it has been found in the Caspian Sea (Korélin, in Mus. Petr.) and at Ayan, in the Sea of Okotsk (Wosnessensiny, in Mus. Petr.). The type of this species is a skin from Greenland; and it is deseribed as not uncommon at St. Michael's, in Alaska; but until we have evidence that it breeds on the American continent we can scarcely consider it as more than au occasional visitant there.

Larus cachinnans, Pall.

Larus affinis is, par excellence, the Arctic Herring-Gull. L. cachinnans might with equal propricty be called the Lake Herring-Gull. It appears to confine itself during the breeding-season to lakes, rivers, and inland seas. It is the common Herring-Gull of the Mediterranean, the only species known at St. Petersburg, and the only species known to breed in the Caspian Sca (Radde \& Karélin, in Mus. Petr.). It is found in the breeding-season near the Aral Sea (Severtzoff, in Mus. Petr.), Lake Saissan (Finsch \& Brehm), S.E. Mongolia (Prejevalsky, in Mus. Petr.), Lake Baical and the island of Olchon, in a lake to the south-cast (Radde, in Mus. Petr.). This Gull has yellow legs when fully adult, with a mantle intermediate in shade between that of $L$. argentutus and L. affinis. Mr. Howard Saunders has also pointed out to me the difference in the respective lengths of the tarsus and the middle toe, including the claw. In $L$. fuscus and L. "Iffinis the tarsus is longer than the foot, whereas in $L$. cachimuns and $L$. argentutus the contrary is the case. In $L$. fuscus and $L$. uffuis it is the exception for the second primary to have a subterminal white spot, whilst in $L$. cachinnans and $L$. argentatus it is the rule.

In the St.-Petersburg Musenu there are three skins of L. occidentalis collected by Wosnessensky on the coast of Southern California. This is a large form of $L$. fuscus, with a short thick bill, very dark mantle, no wedge-shaped markings on the primaries, and, as far as one can judge from dried skins, very yeilow legs. There is also a skin obtained by Wosuessensky at Kodiak, on the North-גmerican coast, which looks like a skin of $L$. argentatus. 
Since my return from Siberia I have received five small collections of birds from Mr. Kibort, a Polish exile whose acquaintance I made at Kras-no-yarsk'. Amongst these are skins of some species which I did not meet with in the valley of the Yen-e-say'. Most of my collecting was done north of the Arctic circle. Mr. Kibort's skins were all obtained in the immediate neighbourhood of Kras-no-yarsk', and illustrate the ornithology of the valley of the Yen-e-say' ten degrees further south of the district where most of my observations were made. I am also indebted to Mr. Meves, of Stockholm, for a report upon the skins obtained by Dr. Théel in the valley of the Yene-say' in 1876. The latter gentleman conducted a scientific expedition which went overland to Siberia, intending to meet Professor Nordenskiold at the mouth of the great river. Dr. Théel was able to reach lat. $70^{\circ}$; but his ornithological booty, owing to the fact that it was principally obtained south of the Arctic circle, contains many species which I did not meet with. He has kindly allowed me to make use of the report of Mr. Meves to supplement my contributions to the ornithology of the valley of the Yen-e-say'.

Pandion haliaetus (Linn.).

Dr. Theel observed the Osprey fishing in the Yen-e-say' in lat. $59 \frac{1}{2}^{\circ}$ and $61^{\circ}$.

Falco esalon, Gmel.

When I was in the valley of the Yen-e-say' I more than once felt almost sure that I recognized the Merlin; but as I did not succeed in obtaining a specimen, it was not included in my first list. I have now the skin of a male in my collection, obtained by Mr. Kibort near Kras-no-yarsk'. Dr. Théel observed it frequently about lat. $70^{\circ}$, and obtained a young bird in lat. $70 \frac{1}{2}^{\circ}$.

Tinnunculus vespertinus (Linn.).

Mr. Kibort has sent me three skins of the Orange-legged 
Hobby from Kras-no-yarsk'. They are of the European form, and not of that obtained by Radde on the Amoor.

Astur palumbarius (Linn.).

Mr. Kibort has sent me a female Goshawk from Krasno-yarsk'.

Circus cineraceus (Mont.).

Mr. Kibort has sent me an adult male of Montagu's Harrier from Kras-no-yarsk'.

Surnia ulula (Limn.).

Mr. Kibort has sent me a skin of a Hawk-Owl from Krasno-yarsk'. Dr. Théel informs me that he met with this species at Luscinova, in lat. $68 \frac{1}{2}^{\circ}$.

Nyctala tengmalmi (Gmel.).

Mr. Kibort has sent me a skin of this Owl from Krasno-yarsk'.

Syrnium uralense (Pall.).

Mr. Kibort has sent me a fine male of the Ural Owl from Kras-no-yarsk'. We might naturally have supposed that it would be intermediate in colour between the European bird and the Japanese subspecies fuscescens, Temm. On the contrary, it differs quite as much from the European bird, but in the opposite direction-the white parts being very white, and the dark parts being very dark and grey, not brown. A careful examination of the skins in the British Museum and in Dresser's and my own collections leads me to the opinion that there is nothing in regard either of size or colour that can entitle the Japanese bird to claim rank even as a subspecies.

Asio accipitrinus (Pall.).

When I was in the valley of the Yen-e-say' I failed to secure a specimen of the Short-eared Owl. Mr. Kibort has now sent me two skins obtained near Kras-no-yarsk'.

UPUPA EPOPS, Linn.

Dr. 'Théel was told, on good authority, that the Hoopoe is occasionally seen near Kras-no-yarsk'.

[80] 
Picus major, Linn.

Dr. Théel found this species breeding near Yen-e-saisk', and met with it as far north as lat. $60^{\circ}$.

Gecinus canus (Gmel.).

Dr. Théel was told, on good authority, that a Green Woodpecker was found near Kras-no-yarsk'.

Picus pipra, Pall.

Mr. Kibort has sent me a skin of this species from Krasno-yarsk'. Dr. Théel informs me that he saw the Lesser Spotted Woodpecker near where the Nish'-ni Tun-goosk' joins the Yen-e-say', in lat. $66^{\circ}$. The whole of the underparts are unspotted silky white, with the exception of the under tail-coverts, which are slightly streaked with black. The outside tail-feathers have two rudimentary cross bars. The transverse bars on the back and rump are also nearly obsolete. The wing measures 3.75 inches, and the tail 2.5 . This species is the Picus kamtschatkensis of Cabanis, Bonaparte, Sundevall, and Malherbe. I have shot it at Archangel and in the valley of the Petchora; and besides the skins from Kras-no-yarsk', I have seen skins from Lake Baical and the Amoor, and have in my collection examples from the islands of Sakhalin and Yezzo, north of Japan. Compared with the South-European form, it is an excellent species. Specimens from Norway and Sweden are somewhat intermediate, being as large as the Siberian form, but in the colour and markings of the back and underparts scarcely differing from the South-European form.

\section{Picus martius, Linn.}

Dr. Théel was informed on good authority that the Black Woodpecker is occasionally seen near Kras-no-yarsk'. He met with it himself in lat. $59^{\circ}$.

IYnX ToRquilla, Linn.

Dr. Théel was informed on good authority that the Wryneck is occasionally seen near Kras-no-yarsk'. He met with it himself in lat. $59 \frac{1}{2}^{\circ}$. 
Sturnus vulgaris, Linn.

Mr. Kibort sent me three skins of the Kras-no-yarsk' Starling. In the P. Z. S. 1878, p. 712, Dr. Finsch has described a new species of Starling from the Chinese High Altai as Sturnus poltaratskyi, and has incorrectly identified the skin I brought from the Yen-e-say' with it. IIe appears to be right in advocating the distinctness of S. humii, Gould (fig. nec descript.), from S. nitens, Hume, which latter species was subscquently renamed (on the ground that the name S. nitens had previously been applicd to the Common Starling by Brehm) S. ambiguus, Hume, and S. humii, Brooks. Finsch, however, is wrong in identifying his species with S. humii, Gould. After carefully examining all the skins in the British Museum and in Dresser's and my own collections, I have come to the following conclusions :-

Sturnus purpurascens, Gould, may at once be recognized by its bronze-purple scapulars and wing-coverts, which in the other species are green. The forehead and ear-coverts appear also to be always bronze-purple. The fore neck is always green, and the breast and belly purple, shading into bronze on the flanks. The remaining parts appear to be subject to variation. The crown, nape, and throat are usually mingled bronze and green, occasionally pure bronze, and occasionally pure green. The upper parts, from the hind neck down wards, are purple in some skins from Eastern Asia Minor, which may be taken as the extreme form. In others, however, from the same locality, and from the Altai mountains and North Persia, these parts are green, in which plumage they are the S. poltaratskyi of Finsch. In the same localities, however, in Asia Minor, in Yarkand, and in North-west India, every intermediate form occurs; so that the probability is that the difference is due to age or individual variation. Gould's type is one of these intermediate forms.

Sturnus vulgaris, Linn., may at once be recognized by its green scapulars and wing-coverts. The car-coverts appear also to be always green. The fore neek is always a reddish purple, and the breast and belly green, shading into bluish purple on the flanks. The crown, nape, and throat are sub[82] 
ject to the same variations as in the preceding species. The upper parts, from the hind neck downwards, are entirely green in skins from Beluchistan, South Persia, Behar, and from Europe to India; but usually the upper back is more or less reddish purple in skins from Europe, and Asia Minor; and in some European skins the upper parts, from the lind neck downwards, are entircly reddish purple. In this ease the intermediate forms are S. vulgaris, Linn.; the green form is S. humii, Gould nee Brooks, and consequently nameless, whilst the reddish-purple form is fortunate enough to have hitherto escaped the infliction of a name. In this case, as in that of S. purpurascens, Gould, since differences of geographical distribution do not coincide with differences of plumage, we may fairly refer the latter to age or individual variation. In the Faroe Islands a form oceurs with a longer bill than usual (S. faroensis, Feilden), which may be worthy of record as a subspecies. A slightly smaller form from the Azores is worthy of honourable mention, but scarcely of the bronze medal of subspecific rank.

Sturnus indicus, Hodgs., appears to me to be a fair species. I take it to be Sturnus unicolor, Marmora, apud Jerdon, S. nitens, Hume nec Brehm, S. ambiguus, Hume, S. humii, Brooks, S. humii, Gould, letterpress nec figure, and S. minor, Hume. It is found in Scinde, Cashmere, and Nepal. It appears to be a small race of $S$. vulgaris, Linn., having the general colour of that bird, and subject to nearly the same variations. The length of wing measures from $4 \cdot 3$ inches to $4 \cdot 75$. The lower back and rump are often green; but I have not yet met with a skin in which the upper back was green. The flanks, however, appear to be always green, whereas they seem to be always purple in the common species.

The breast appears also to be always purple, whilst in $S$. vulgaris the purple does not extend below the lower throat. I take it to be a good species.

Oriolus galbula, Linn.

Mr. Kibort has sent me a male of this species from Kras- 
no-yarsk', the most easterly locality hitherto recorded of the Golden Oriole.

\section{Lanius homeyeri, Cab.}

Great differences of opinion appear to exist as to the number of species into which the Grey Shrikes ought to be divided. Dresser and Sharpe, in their "Notes on Lanius excubitor and its Allies" (P.Z.S. 1870, p. 590), recognized two Siberian species. Two skins from the Amoor, fortunately still in the Swinhoe collection, were identified by these ornithologists as adult and immature of Lanius lahtora (Sykes). The adult bird is stated to be "absolutely similar in every respect" (the italics are not mine) to examples of old $L$. lahtora from the Punjab. The second Siberian species was identified doubtfully, from Pallas's description of $L$. major, with the American $L$. borealis, Vicill. I think Dresser and Sharpe were wrong in both their faets, but right in at least one of their conclusions. The adult bird of the first species, so far from being absolutely similar in every respect to $L$. lahtora, differs from that species in having the general colour of the upper parts considerably paler, and in wanting the narrow black frontal line at the base of the bill. The immature bird is what is generally recognized as L. major, Pall., which these writers professed never to have seen.

In the 'Journal für Ornithologie' (1873, p. 75) the subject is handled by Cabanis with that minute attention to details so characteristic of the German mind, and two new species are described, $L$. homeyeri and $L$. sphenocercus. In addition $L$. major, Pall., is recognized as a Sibcrian bird.

We may at once dismiss $L$. meridionalis, Temm., and $L$. algeriensis, Less., as western forms, which have nothing to do with Siberia. L. lahtora, Sykes, seems to me to have no better claim to be considered a Siberian bird. In the allied species black hairs, apparently an extension of the rictal bristles, are found on the forehead at the base of the bill; but in L. lahtora, Sykes, more or less black feathers are found there in addition, causing it to approach in this respect $L$. excubitoroides, Swains., where these black feathers are still more 
developed. L. lahtora, Sykes, is probably entirely confined to India, where it breeds-though L. leucopygius, Hempr. apud Severtz., from Turkestan, may prove to be this species. The skin from the Amoor in the Swinhoc collection, which Sharpe and Dresser incorrectly identified with L. lahtora, Sykes, appears to me to be $L$. homeyeri, Cab., originally described (loc. cit.) from South Russia. Hence it passes eastwards through Turkestan, where it has been described by Severtzoff as L. leucopterus (Ibis, 1876, p. 184), to Central Siberia, whence Mr. Kibort has sent me two skins obtained by him at Krasno-yarsk' on the 18th of May and the 12th of August. Eastwards it appears to be found near Lake Baical (Tacz. Journ. f. Orn. 1874, p. 322) and on the Amoor. In this species, as in L. lahtora, Sykes, the secondaries are not only tipped with white, but are always white on the basal half of both webs, and some of them are always white on the entire inside web. A third species having this peculiarity appears to be $L$. dealbatus, Defil., from Algeria, Tunis, and Sennaar (fide skins in the British Museum). This species appears to be intermediate in the colour of the upper parts between L. lahtora, Sykes, and L. homeyeri, Cab., differing also from the former in wanting the narrow black frontal line of feathers, and from the latter in its smaller size and distinct geographical range.

\section{Lanius major, Pall.}

My immature bird from the Amoor is undistinguishable from $L$. borealis, Vieill.; but I have seen an almost complete series from it to L. excubitor, Linn. That the amount of white at the base of both webs of the secondaries is not a question of age, appears to me to be sufficiently proved by the skin of a nestling from Baden in Dresser's collection, in which the white on the secondaries is as much developed as in typical skins of fully adult $L$. excubitor, Linn. The only explanation that I can suggest is that $L$. excubitor, Linn., is the western form, which in Europe may be said to be almost pure-bred. In Asia it would appear to interbreed along the whole line with $L$. borealis, Vieill., which becomes the pre- 
vailing form in East Sibcria. In America probably only pure-bred L. borealis, Vieill., occurs ; whilst in Asia purebred birds of both specics, and every possible cross and intercross between them, are to be found.

Another species allied to L. excubitor, Linn., appears to be L. fallax, Finsch, differing in being somewhat smaller in size, darker in the colour of the upper parts, and in having the white on the primaries and sccondaries more developed but nevertheless not extending over the entire inside webs of any of the sccondaries. Dresser and Sharpe apparently include this species in their L. lahtora, Sykes; but it does not seem to possess the narrow black frontal line. From skins in the British Museum and in Dresser's collection I conclude the geographical range of $L$. fallax, Finsch, to be Abyssinia, Nubia, Egypt, Palestine, Euphrates valley, Baluchistan, and the Punjaub, in which latter district it is found in company with $L$. lahtora, Sykes. I strongly suspect that the " $L$. leucopygius, Hempr." apud Severtz., will also prove to be $L$. fallax, Finsch, since the skin which Finsch brought from the Irtish appears to be of the latter species, though larger in size than usual. Since the geographical ranges of all the Grey Shrikes more or less overlap each other, I should not be surprised to learn that in many cases where two forms inhabit the same district they habitually interbreed. In that case one of the forms thus interbrecding would have to be degraded to the rank of a subspecies; but until intermediate for'ms are found, we must, I think, consider them as closely allied but distinct species, and not lump three or four of them together, as Sharpe and Dresser appear to me to have done.

Lanius sphenocercus, Cab.

This Shrike is fairly figured in David and Oustalet's 'Oiseaux de la Chine,' plate 76. It appears to breed in Eastern Siberia (Tacz. Journ. f. Orn. 1876, p. 198), to pass through Mongolia on migration (Prjev. Rowl. Orn. Misc. ii. p. 273), and to winter in China (David et Oustal. Ois. Chine, p. 93).

Lanius cristatus, Linn.

Mr. Kibort has sent me three skins of the adult and two 
skins in the immature plumage of this species. Dr. Theél obtained eggs of this bird. I take it to be the L. phonicurus of Pallas, and the L. superciliosus of Latham.

Garrulus brandti, Eversm.

'This very handsome and rare Jay appcars to be very common in the neighbourhood of Kras-no-yarsk'. Mr. Kibort has sent me numerous skins.

\section{Perisoreus infaustus (Linn.).}

Mr. Kibort has sent me two skins of the Siberian Jay from Kras-no-yarsk'. Dr. Theél informs me that he met with this species at various stations on the Yen-e-say' up to the Arctic circle.

Uragus sibiricus (Linn.).

Mr. Kibort has sent me three skins of this brilliantly jlumaged bird from the neighbourhood of Kras-no-yarsk'. Dr. Theél obtained it at Yen-e-saisk'.

Cardulis orientalis, Eversm.

Mr. Kibort has sent me a fine male of this species from Kras-no-yarsk'.

Coccothraustes vulgaris, Pall.

Mr. Kibort has sent me two skins of the Hawfinch from Kras-10-yarsk'. They agree exactly with others from Asia Minor and Japan.

\section{Loxia curvirostra, Linn.}

Mr. Kibort has sent me two skins of the common Crossbill from Kras-no-yarsk'.

Loxia bifasciata, Brehm.

Dr. Theél informs me that he met with small parties of this species between Kras-no-yarsk ${ }^{\prime}$ and Yen-e-saisk'.

Fringilla montifringilla, Linn.

Dr. Theél informed me that he saw two examples of this species in lat. $59^{\circ}$ on the 26th of June.

Passer montanús (Linn.).

Dr. Theél informed me that he saw the Tree-Sparrow as far north as lat. $60^{\circ}$. 
Emberiza spodocepirala, Pall.

Mr. Kibort has sent me a skin of this species from the neighbourhood of Kras-no-yarsk'. Dr. Theél also obtained it there and at Asinova, in lat. $61^{\circ}$.

Emberiza aureola, Pall.

Mr. Kibort has sent me the nest and eggs of this species from Kras-no-yarsk'.

Emberiza pusilla, Pall.

Dr. Theél obtained this species in lat. $65^{\circ}$ on the 13 th of July.

Emberiza cioides, Brandt.

I have received seventeen skins of this handsome Bunting in autumn plumage, and two skins in breeding-plumage, from Kras-no-yarsk'. In both plumages the ear-coverts are deep reddish brown, instead of black as in its Japanese ally, E. ciopsis, Bp. All the skins of E. ciopsis, Bp., from Japan which I have seen in collections in this country have black ear-coverts; but in the Leyden museum both species are labelled as coming from Japan.

Alauda Arvensis, Linn.

Mr. Kibort has sent me several skins of the Sky-Lark from the neighbourhood of Kras-no-yarsk'. They all appear to be identical with our European species, and differ from the Japanese form in being paler on the upper parts.

Alauda pispoletta, Pall.

Mr. Kibort has sent me a skin of this species from Krasno-yarsk'.

Anthus cervinus, Pall.

This species was first met with by Dr. Theél on the 25th of July in lat. $69^{\circ}$, which is probably the southern limit of its range in the breeding-season.

Anthus trivialis (Linn.).

Dr. Theél found this species as far north as lat. $69^{\circ}$.

Anthus godlewsini (Tacz.), Bull. Soc. Zool. France 1876, p. 158.

Mr. Kibort has sent me two skins, obtained near Kras-no[88] 
yarsk', which appear to be the same form as Taczanowski's new species obtained by Dr. Dybowsky near Lake Baical and by Prjevalsky in Alaschan, in Chinese Mongolia. This species seems to me to be a good one. It is nearly allied to A. campestris, but is decidedly smaller and darker in colour on the upper parts.

Anthus maculatus, Hodgs.

Mr. Kibort has sent me a skin of this Pipit, which differs from the Tree-Pipit in being much greener on the upper parts and somewhat more spotted on the underparts.

Motacilla flava, Linn.

I am unable to distinguish skins of this species obtained at Kras-no-yarsk' from skins collected in Holland.

Motacilla personata, Gould.

Dr. Theél informed me that he did not see this Wagtail further north than lat. $59^{\circ}$. A few versts further north its place was taken by $M$. alba.

Motacilla melanope, Pall.

Dr. Theél informed me that he found this species brecding in lat. $59^{\circ}$.

Motacilla citreola, Pall.

Dr. Theél informed me that he first met with this species in lat. $65^{\circ}$, on the 11 th of July, where it was doubtless breeding at or near its southern limit in summer.

Ampelis garrula, Linn.

I did not succeed in shooting a specimen of the Waxwing in the valley of the Yen-e-say'; but Mr. Kibort has sent me three skins from Kras-no-yarsk', and Dr. Theél informs me that he found this species common in several localities.

Parus cyanus, Pall.

I have received three skins of this bird from Kras-noyarsk'.

Acredula caudata (Linn.).

The Long-tailed Tit appears to be common in the neighbourhood of Kras-no-yarsk'. Mr. Kibort has sent me 
eight skins. The Siberian form is very beautiful, and almost entitled to rank as a subspecies. The entire bead and neck are pure white. The whole of the inside webs of the innermost secondaries are also pure white. In the British and CentralEuropean forms the white on the wing is much less developed; but intermediate forms are not uncommon in North Europe. Dr. Theél informs me that he saw this species as far north as lat. $59^{\circ}$.

\section{Cinclus leucogaster, Bonap.}

Bonaparte, in his 'Conspectus' (i. p. 252), ascribes this name to Eversmann; but $I$ have been unable to find a reference to any publication of the name earlier than that of Bonaparte. Mr. Kibort has sent me two skins of a Dipper from the neighbourhood of Kras-no-yarsk', which I presume must belong to this species. Both are males; and both were shot on the same day, the 17 th of November. The head and nape are sooty brown, much darker than in C. albicollis, and not so rufous as in $C$. aquaticus. The underparts of one skin agree with those of $C$. melanogaster; but in the other the white on the breast extends further down, and instead of being sharply divided from the sooty black of the belly it gradually shades into it, passing through the various shades of greyish brown. The genus Cinclus presents many difficulties. Dresser, in his 'Birds of Europe,' adds little or nothing to the facts collected by Salvin in 'The Ibis' of 1867 , p. 109 et seq. I fail to be able to draw the distinction which Salvin does between local races and represcntative species. If he were to examine the additional material which has come to hand since his article was written, I think he would agree with me that his local races are those of which he possessed a large series, whilst of. his representative species he was only able to obtain access to one or two skins. So far as I can see, there is only one species of Palarearetic White-throated Dipper, of which the typical form inhabits Central and Southern Siberia, North India, Turkestan, Persia, and Asia Minor, and will probably stand as C. cashmiviensis, Gould. In East Siberia every intermediate [90] 
form occurs between this and C. leucogaster, Bonap., the extreme type of which has the underparts white throughout. In Europe three subspecies have apparently established themselves:-C. melanogaster, Brehm, in the north, in which the dark parts are intensified in colour and a shade of rufous is observable on the head and nape; C. aquaticus, Bechst, in Central Europe, in which the rufous shade appears on the belly also; and C. albicollis, Vieill., in Southern Europe, in which the head and nape are paler brown than in the typical species.

Turdus obscurus, Gmel.

Dr. Theél informed me that he obtained a specimen of this Thrush as far north as lat. $68^{\circ}$.

\section{Turdus sibiricus, Pall.}

Dr. Theél informed me that the great breeding-place of this beautiful and rare Thrush is in the neighbourhood of 'Toor-o-kansk', about lat. $66^{\circ}$. He did not observe it further north than E-gar'-ka, in lat. $67^{\circ}$.

Turdus musicus, Linn.

Mr. Kibort has sent me both adult and young in first plumage of the Song-Thrush. From the presence of the latter we may, I think, safely infer that this bird breeds near' Kras-no-yarsk'. I am not aware of any instance on record of any Thrush migrating before moulting.

Ruticilla phenicurus (Linn.).

Mr. Kibort has sent me a skin of the Common Redstart from the neighbourhood of Kras-no-yarsk'-a male in breeding-plumage; so that no doubt can now attach to the easterly range of this species.

\section{Cyanecula suecica (Linn.).}

Mr. Kibort has sent me a skin of this species, from Krasno-yarsk', in the spotted plumage of the young before migration, whence I conclude that the Blucthroat occasionally breeds as far south as lat. $56^{\circ}$. 
192 Mr. II. Seebohm on the Ornithology of Siberia.

Saxicola isabellina, Rüpp.

Mr. Kibort has sent me two skins of this Chat from Krasno-yarsk'.

Muscicapa grisola, Linn.

Mr. Kibort has sent me four skins of the Spotted Flycatcher obtained near Kras-no-yarsk'.

Muscicapa parva, Bechst.

Dr. Theél obtained a female of this species in lat. $61_{4}^{1}$.

Alseonax latirostris (Raff.).

Mr. Kibort has sent me three skins of this Flycatcher from Kras-no-yarsk'.

Arundinax aedon (Pall.).

Mr. Kibort has sent me three skins, from the neighbourhood of Kras-no-yarsk', of this interesting bird.

Hypolais caligata (Eversm.).

Mr. Kibort has sent me three skins of this species from Kras-no-yarsk'. I think there can be little doubt that this bird is the Motacilla salicaria of Pallas. Dr. Theél obtained a specimen in lat. $61^{\circ}$.

Phylloscopus fuscatus, Blyth.

Dr. Theél found this species as far north as lat. $59^{\circ}$.

Phylloscopus trochilus (Linn.).

The name of this species does not occur in the list of skins, identified by Mr. Meves, obtained on the Swedish expedition. I found it plentiful in the valley of the Yen-e-say'.

Locustelia certhiola (Pall.).

Dr. Theél obtained an adult bird of this species in lat. $62^{\circ}$.

Acrocephalus dumetorum, Blyth, J. A. S. B. xviii. p. 815. Mr. Kibort has sent me several slins of this bird from Kras-no-yarsk'. Dr. Theél describes it as common between that town and Yen-e-saisk'. He found it breeding in lat. 59 , and obtained a nest with two eggs. Mr. Meves describes the eggs as similar to those of Locustella navia, having a pale rust-red ground-colour, with many greyish-red spots. 
Cypselus apus (Linn.).

Dr. Theél informs me that he observed the Swift abundant at Kras-no-yarsk' and Yen-e-saisk'. He afterwards observed it in lat. $60^{\circ}$, and again in lat. $65 \frac{1}{2}^{\circ}$.

Caprimulgus europedes, Linn.

Mr. Kibort has sent me the skin of a female Goatsucker from Kras-no-yarsk'. Dr. 'Theél recognized its peculiar note in lat. $59^{\circ}$.

Alcedo ispida, Linn.

Dr. Theél informs me that he saw a Kingfisher near Krasno-yarsk'.

Columba palumbus, Linn.

Dr. Theél was informed on good authority that the RingDove occasionally occurs near Kras-no-yarsk'.

Columba enas, Linn.

Dr. Theél was informed that the Stock-Dove is occasionally found near Kras-no-yarsk'. He saw a bird which he took to be this species at Nasimova, in lat. $59 \frac{1}{2}^{\circ}$.

Coturnix communis, Bonnat.

Mr. Kibort has sent me a skin of the common Quail from Kras-no-yarsk'; and Dr. Theél heard its unmistakable note in lat. $61^{\circ}$.

Strepsilas interpres, Linn.

Dr. Theél observed this species in lat. $70 \frac{1}{2}^{\circ}$.

Agralites curonica (Gmel.).

Dr. 'Theél found this species breeding at Yen-e-saisk', and observed it as far north as lat. $60 \frac{1}{2}^{\circ}$.

Crex pratensis, Bechst.

Dr. Theél observed the Corn-crake at Kras-no-yarsk' and as far north as lat. $59 \frac{1}{2}^{\circ}$.

Totanus fuscus (Linn.).

Dr. Theél observer this species about lat. $69^{\circ}$, and obtained a young bird. 
Calidris arenaria (Linn.).

Numerous flocks of this species were seen by the Swedish Expedition of 1875 at the mouth of the Yen-e-say'.

\section{Tringa temmincki, Leisl.}

This species was first met with by Dr. Theél on the 22nd of July, in lat. $65 \frac{1}{2}^{\circ}$, which probably represents the southern limit of its breeding-range.

Anas boschas, Linn.

Dr. Theél observed the Mallard up to lat. $60^{\circ}$.

Fuligula cristata (Leach).

Dr. Theél shot a Tufted Duck in lat. $68^{\circ}$.

EDemia Fusca (Linn.).

Dr. Theél observed the Velvet Scoter in lat. $69^{\circ}$ and $69 \frac{1}{2}^{\circ}$.

Sterna longipennis, Nordm.

Dr. Theél obtained a Tern in lat. $63^{\circ}$, which Mr. Meves has identified as belonging to this species.

In my first paper on the ornithology of Siberia, I fear that I scarcely did justice to Prjevalsky. It appears that I was misinformed as to the scientific knowledge of ornithology possessed by this great traveller. His fame as an explorer of almost unknown districts of Central Asia, however, is so great that it almost obscures the fact that he has added very largely to our knowledge of the ornithology of that interesting region.

I may also take this opportunity of expressing my profound regret at the untimely death of my friend, Valerian von Russow. He had been engaged for some months in an ornithological expedition in Turkestan. Just before his return home I had a letter from him, dated Samarcand, telling me of his success; the next intelligence I received was that he had died of smallpox within a week of his arrival in St. Petersburg. In Russow ornithology has lost an enthusiastic field-naturalist, who was rapidly acquiring the scientific knowledge of birds which can only be attained where large scrics of skins are available for comparison. 
Mr. H. Seebohm on the Ornithology of Siberia. 195 His position in the St.-Petersburg Museum is now filled by Modeste Bogdanow, who has lately published a work on the Birds of the Caucasus, and whose recently issued article on the Birds of the Black-earth Zone of the Volga and its Central and Lower valleys contains some excellent field-notes. 
$3 \cdot 5,2 \ldots$ A exilines

An cor Ge. Thro fwo

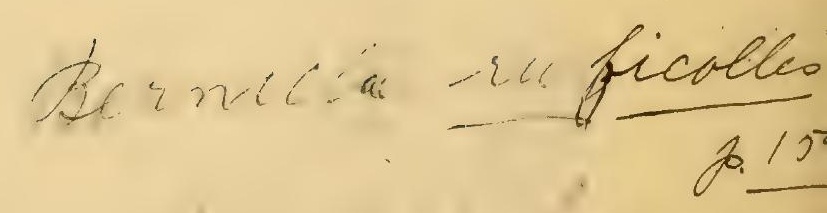

E2vata-

336 
colanuper/ac - Is

Areceling Tirive

Crow, carrion, 33I.

(facenee oft, 327

Cuckoo, (SiD), , - 326

LUCK-- Finta 1 I, I60

Buntivg (Ain) 33 slaen, eve, I6o

Dotterel-155 leasiless levetedon

poisn, or.

Fieffare, [2]

Fildeni- ane. Expeci-15!

$\left.0: 1,0 v_{i}, 10\right]$

Sibertar, If?

$$
\text { Knot }=151
$$

Lagopus abres [f. W. K.rup-14

Locusteler $-\left[\begin{array}{ll}1 & 3\end{array}\right]$ 
notacelle alda - 343

m. oureris, $3 \%$

nc. luyeno, 347.

init, (Re(i-throut), 433

Ptarmican, (Fock, )I48

Red-jollo, ( Inter gradesing,

Alribled Intortocedeng 1,86 
Nutcracler, 333

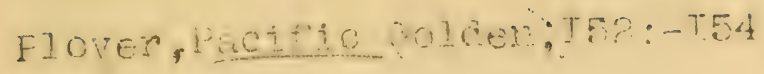

$=0 d-519) 1,(1006 x),-3=$

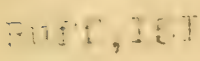

Nadpluen, Gurzep, T5

W0od, (EIresiz), I5E

Greet. 156

Sibirichi Reial-340

snive, Common, I5E

Starnos $(2 x-2) 182$

Sparrow, (finte) - 337

" hensily,

[3] Thusk vant

Gundra $=[3]$

Weriler; (Blue-innout) ,7 \& ISI

co.w1770w arfent ear \& 




SMITHSONIAN INSTITUTION LIBRARIES 